\title{
SOIL CONDITIONS AND XEROTHERMIC GRASSES COMMUNITIES WITHIN THE WESTERN EDGE OF THE ODER IN THE VICINITY OF SZCZECIN
}

\section{WARUNKI GLEBOWE ORAZ ZBIOROWISKA MURAW KSEROTERMICZNYCH NA ZACHODNIEJ KRAWĘDZI ODRY W POBLIŻU SZCZECINA}

\author{
Department of Ecology, Environmental Protection and Development, West Pomeranian University \\ of Technology, Szczecin, Poland \\ 1Department of Plant Physiology and Biochemistry, West Pomeranian University of Technology, \\ Szczecin, Poland \\ 2Department of Soil Science, Grassland and Environmental Chemistry, West Pomeranian University \\ of Technology, Szczecin, Poland
}

\begin{abstract}
Streszczenie. Na podstawie 29 zdjęć fitosocjologicznych, wykonanych na obszarze krawędzi Odry Zachodniej (Ustowo-Pargowo), wyróżniono dwa zespoły muraw kserotermicznych. Fitocenon Potentillo-Stipetum capillatae jest wewnętrznie zróżnicowany na wariant typowy ze znacznym udziałem gatunków zbiorowisk zaroślowych z Rhamno-Prunetea. Strukturę zespołu tworza, poza licznymi gatunkami muraw kserotermicznych, także taksony muraw piaskowych z Koelerio glaucae-Corynephoretea canescentis (szczególnie często i licznie występują: Sedum acre, Festuca ovina i Helichrysum arenarium). Płaty tego fitocenonu występują zarówno na glebach słabo ukształtowanych erozyjnie (SY), wytworzonych z piasków gliniastych (pg), jak i na glebach brunatnych eutroficznych typowych (BEt) wytworzonych z gliny lekkiej (gl). Fitocenozy Adonido-Brachypodietum pinnati tworzą zwarte murawy z dominacją Brachypodium pinnatum i z przewagą traw z Molinio-Arrhenatheretea (Arrhenatherum elatius, Festuca rubra, Dactylis glomerata) oraz ze znacznym udziałem gatunków zbiorowisk zaroślowych z Rhamno-Prunetea. Płaty roślinności wykształciły się głównie na glebach brunatnych eutroficznych typowych (BEt), wytworzonych z gliny piaszczystej (pg) i gliny lekkiej ( $\mathrm{gl}$ ). Typologicznie zróżnicowane gleby na zboczach krawędzi charakteryzują się odczynem zasadowym i znaczną zawartością węglanu wapnia. Ekspozycje zboczy S i SE oraz warunki glebowe sprzyjają występowaniu muraw kserotermicznych i piaskowych. Częsta i liczna obecność gatunków zbiorowisk zaroślowych (Rhamno-Prunetea) w części płatów obu zespołów oraz traw z Molinio-Arrhenatheretea wskazuje na stadium pośrednie w sukcesji zmierzającej do wykształcenia się zbiorowisk seminaturalnych, z także zaroślowych. W celu zachowania unikatowej flory i zbiorowisk na tym obszarze należałoby stosować ekstensywny sposób jego użytkowania (wypas, koszenie).
\end{abstract}

Key words: xerothermic grasslands, phytosociological stability, cover coefficient, soil conditions, plant communities: Adonido-Brachypodietum pinnati, Potentillo-Stipetum capillatae.

Słowa kluczowe: murawy kserotermiczne, stałość fitosocjologiczna, współczynnik pokrycia, warunki glebowe, zbiorowiska roślinne: Adonido-Brachypodietum pinnati, Potentillo-Stipetum capillatae.

Corresponding author - Adres do korespondencji: Katarzyna Malinowska, Department of Plant Physiology and Biochemistry, West Pomeranian University of Technology, Szczecin, Juliusza Słowackiego 17, 71-434 Szczecin, Poland, e-mail: katarzyna.malinowska@zut.edu.pl 


\section{INTRODUCTION}

Xerothermic grasslands are widespread in southern and south-eastern Europe. Their natural, non-forest character is due to the specifics of climate characterized by hot and dry summer, harsh winter, strong winds and predominance of evaporation over precipitation (Jermaczek et al. 2005).

In Poland they are found on vast hills' slopes, on relatively small and steep parts of big rivers' valleys edges and their Urstromtäler, moraine hills, uplands, rocky outcrops, and sometimes on slopes of anthropogenic origin - slopes of artificial embankments, excavation pits and spoil tips exposed to the south (Barańska and Jermaczek 2009). They mainly inhabit sunny slopes of southern, south-eastern, south-western and western exposition of limestone ground. They are also found on limestone, southern slopes of depleted quarries (Kostuch and Misztal 2006, Kutyna and Malinowska 2012, 2015a, b). These are however separate sites. Xerothermic grasslands with their unique flora and fauna are among the most valuable and the most endangered elements of environment in Poland and Europe and were therefore included in Annex I of the Habitats Directive (Directive 92/43/EEC on the Conservation of natural habitats and of wild fauna and flora) of European Union as the habitat of particular importance to be protected in all member countries of EU. Xerothermic grasslands are considered to be among floristically richest plant communities composed of many protected and rare, often relict, plant species.

Xerothermic grasslands currently belong to seriously endangered areas. This is due to their limited cover area, large dispersion (small isolated areas) and the departure from agricultural use which is an important factor forming those communities (Perzanowska and KujawaPawalczyk 2004). Unfortunately, extensive pastoral use, which contributed to the formation of xerothermic grasslands, is disappearing resulting in overgrowing, shrub and forest formation as well as the degradation of communities converting into grassy vegetation (Bąba 1999).

Xerothermic vegetation is found i.a. on sunny steep slopes of western edge of the Oder valley in the area from Pargowo in the south to Ustowo in the north. It is a relict element of vegetation of Western Pomerania occurring to the south from the Oder River. Xerothermic flora developed in the area due to specific microclimatic conditions on southern, south-western and south-eastern slopes. Some years, the macroclimate in the area reveals the features of continental climate (annual precipitation is at $500-550 \mathrm{~mm}$ ). The soils on the slopes are characterized by alkaline reaction regardless the particle size distribution.

One of the best preserved sites of xerothermic grasslands are found in western Poland. They are found on the edges of Oder, Warta and Noteć rivers. Starting from the mouth of Warta to Oder in the direction of Szczecin, they were described in this area by: Celiński and Filipek (1958), Radomski and Jasnowska (1964, 1965), Filipek (1974a, b), Ćwikliński (1982), Friedrich (2000), Friedrich and Semczyszyn (2002). Particularly noteworthy are also grasslands found in the vicinity of Owczary and Górzyca in Lubuskie voivodship (Kutyna et al. 2011, 2012).

The aim of the study is to determine soil conditions (soil types and their basic parameters) as well as to describe xerothermic grasslands communities found on the edge of Western Oder in the area from Pargowo to Ustowo. 


\section{NATURAL CONDITIONS}

\section{Location of the study area}

On Polish territory, the edge of the Oder River stretches from Pargowo in the south and it reaches Ustowo in the north, and then after about $5 \mathrm{~km}$ it reaches the northern district of Szczecin-Skolwin (Fig. 1). Almost the whole area belongs to Kołbaskowo municipality. On flat areas in the west from the edge, there are mainly cropped lands with segetal communities developing within them. There can also be found patches of meadows with grassland phytocoenoses, as well as fallow lands and pastures inhabited by grassland and shrubland communities. On the edge of Western Oder there are much less arable lands. This part of area is to a great extent naturally forested, at some places spontaneously occupied by shrub vegetation. Enclaves of xerothermic and sandy grasslands can be found on the slopes of the edge. The north-western part of the edge is characterized by patches of meadow steppe dominated by tor-grass (Brachypodium pinnatum). The area of grassland occurrence is diminished from year to year due to ever-increasing encroachment of shrub and forest vegetation. Lack of animal grazing as well as mowing or controlled burning of the area in order to preserve xerothermic vegetation, contributes to the decline of grasslands.

\section{Soil conditions}

The soil study was performed on the slopes of the left edge of Oder in the area from Pargowo to Ustowo (Fig. 1-4).

The soils with xerothermic grasslands and sandy soils were formed in specific ecological conditions which include significant inclination of the slopes, the direction of their exposure, soil and water conditions as well as vegetation. As a result, the areas have specific soil conditions and microclimate.

The study by Borowiec (1993) shows that in the southern part of the area (Pargowo Waliszewo) pararendzinas were formed from boulder clay rich in $\mathrm{CaCO}_{3}$, which is rare soil in Western Pomerania. In central and northern parts - Siadło Górne - Kurowo - Ustowo, brown soils are found, formed from more or less sandy boulder clay. In the southern part of the area (Kamieniec - Kamionka), there occur deluvial soils formed from sands.

The alkaline $\mathrm{pH}$ of the soil and its dry and warm habitats create optimal conditions for the development of xerothermic grasslands, and in the areas of agricultural use for segetal habitats of diverse floristic composition with numerous rare xerothermic and calciphilous species (Kutyna et al. 2016)

\section{Climatic conditions}

Apart from soil conditions, growth and floristic structure of communities are significantly influenced by climate. In this case, they are also influenced by microclimate within slope surface, both open and surrounded by dense forest stands or scrubs. The study area is mainly affected by oceanic climate, and in a significant number of years climate parameters (precipitation, air temperature) characteristic of continental climate can also be observed. 


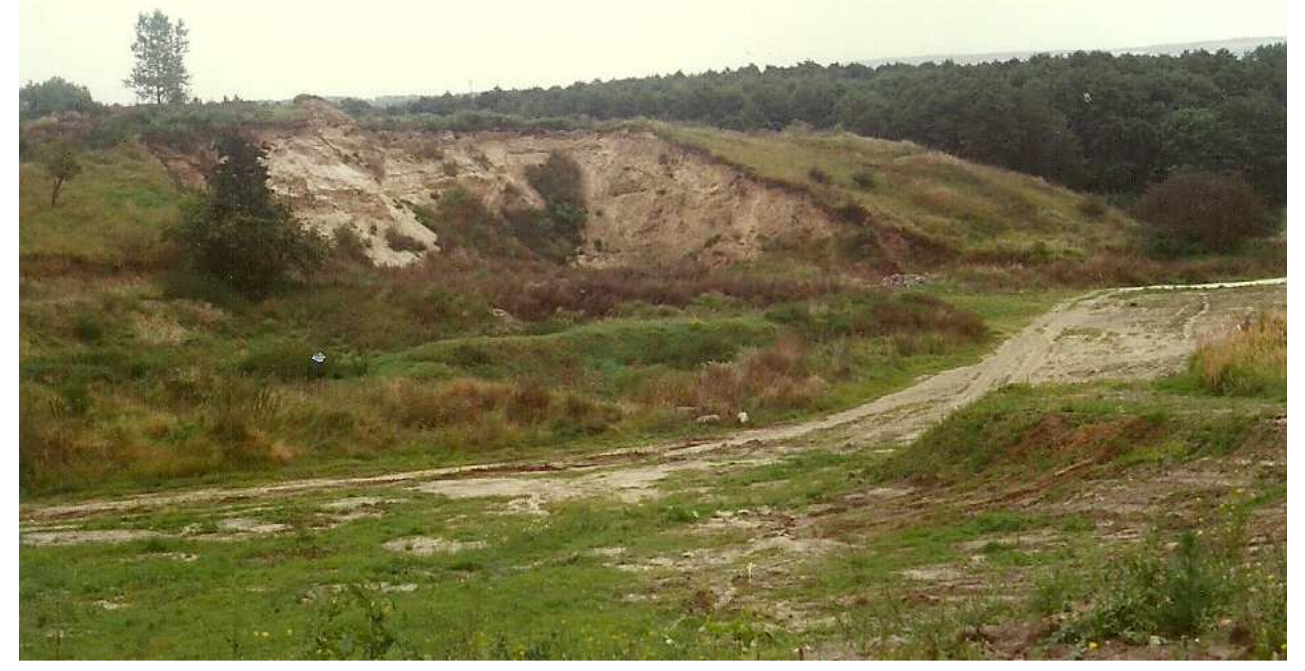

Fig. 1. The excavation of the unveiling of the natural soil in Kurowo; in the neighborhood occur xerothermic turfs (photo I. Kutyna)

Ryc.1. Wyrobisko z naturalnym odsłonięciem gleby w Kurowie; w sąsiedztwie występują murawy kserotermiczne (fot. I. Kutyna)

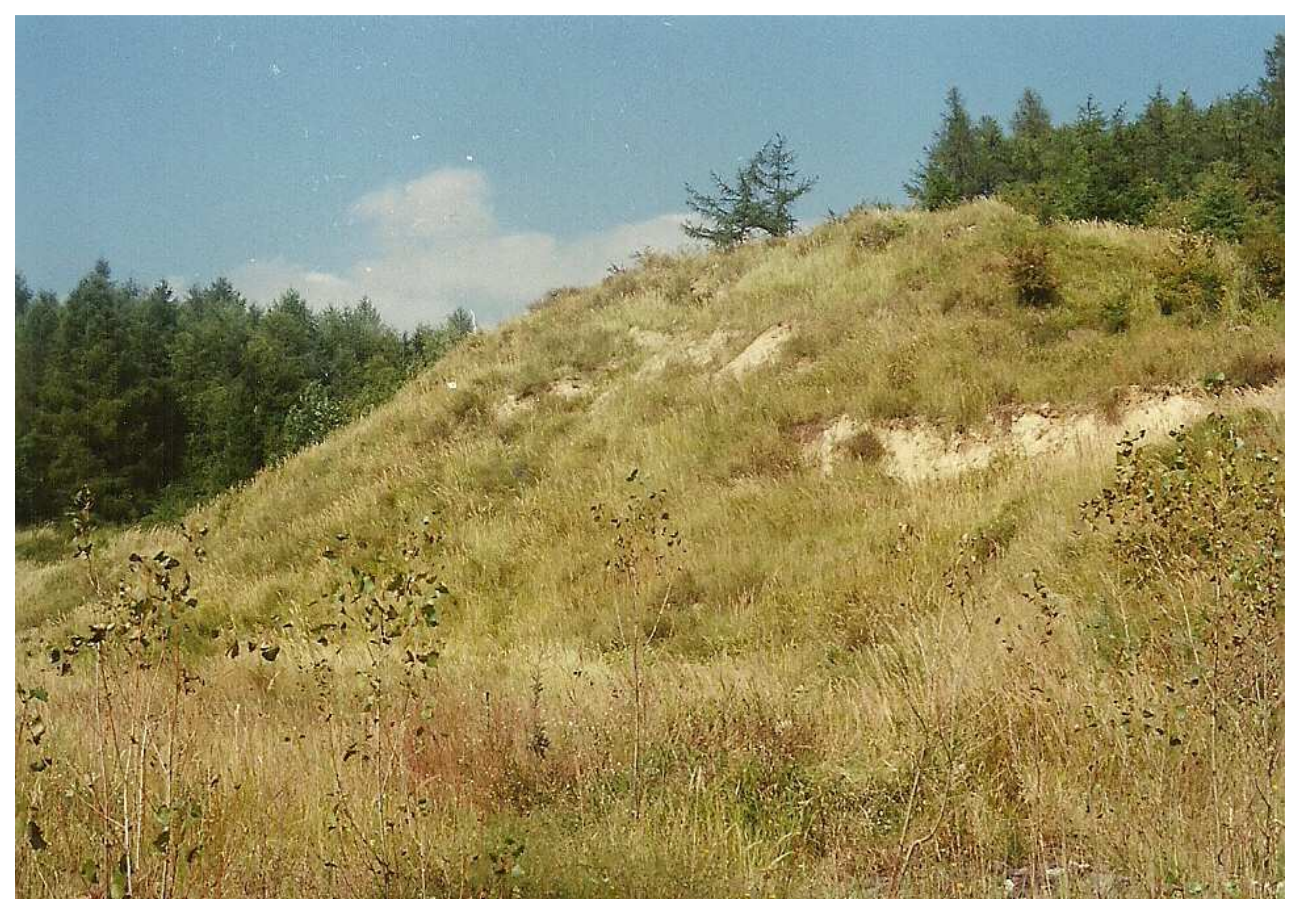

Fig. 2. Southern slope of xerothermic turf in Waliszewo with visible natural soil unveiling (photo I. Kutyna)

Ryc. 2. Południowe zbocze z murawą kserotermiczną w Waliszewie, widoczne naturalne odsłonięcia glebowe (fot. I. Kutyna) 


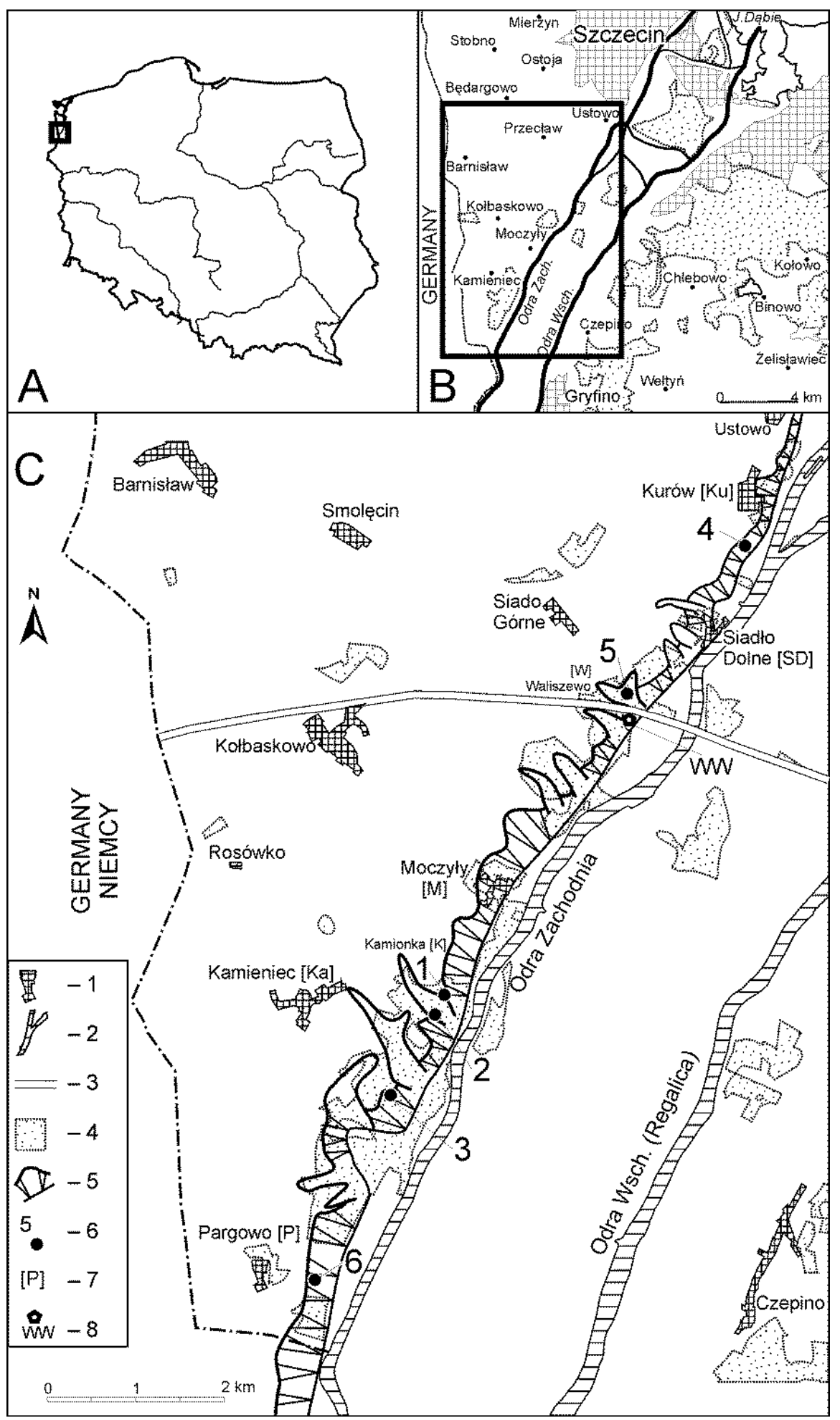

Fig. 3. Location of the study area on the Polish area (A) and near Szczecin (B) and placement of test points on the left edge of the Odra valley (C). 1 - villages, 2 - surface water, 3 - highway, 4 - forests, 5 - the edge of the Odra valley, 6 - soil pits, 7 - the villages abbreviations, 8 - nature reserve "Wzgórze Widokowe"

Ryc. 3. Położenie obszaru badań w Polsce (A) i w okolicach Szczecina (B) oraz rozmieszczenie punktów badań na lewej krawędzi doliny Odry (C). 1 - miejscowości, 2 - wody powierzchniowe, 3 - autostrada, 4 - lasy, 5 - krawędź doliny Odry, 6 - odkrywki glebowe, 7 - skróty nazw miejscowości, 8 - rezerwat przyrody „Wzgórze Widokowe” 


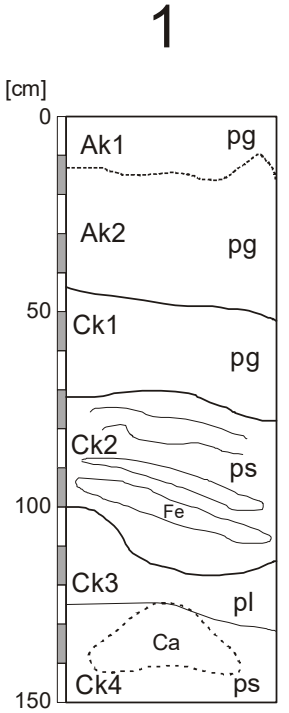

4

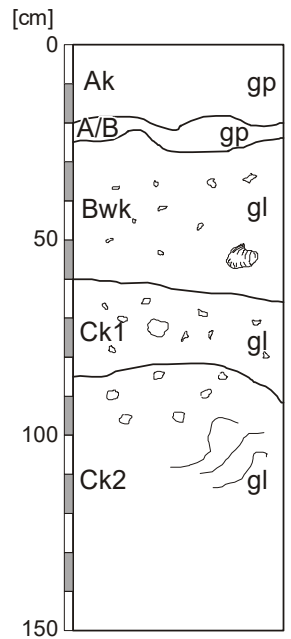

2

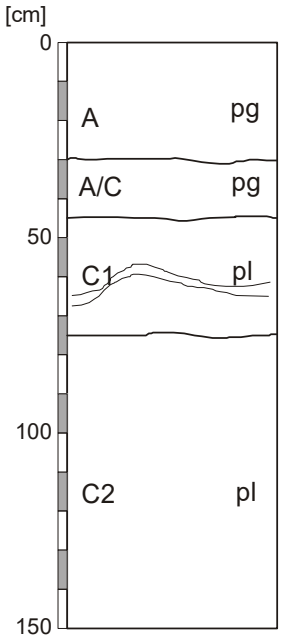

5

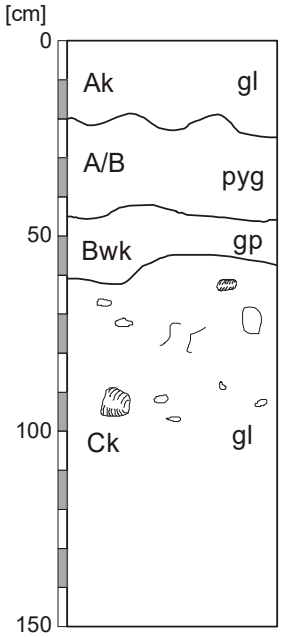

3

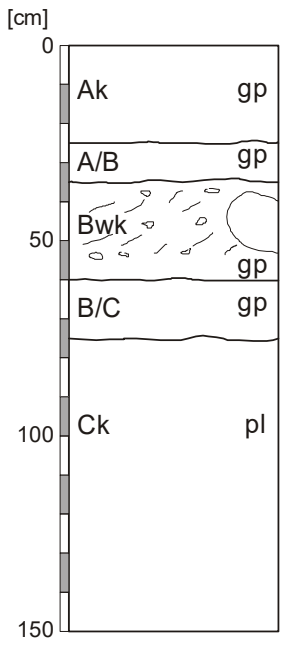

6

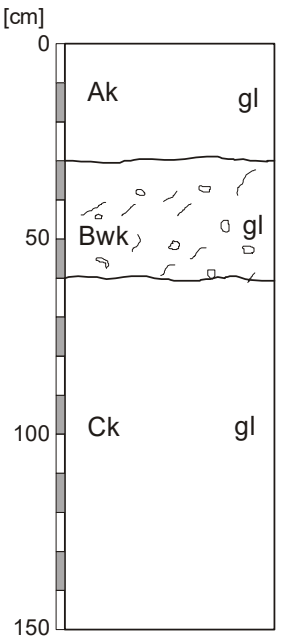

Fig. 4. Six soil profiles made in the area of the western edge of the Odra valley south of Szczecin (soil types and particle size of genetic horizons are given in Table 1)

Ryc. 4. Sześć profili glebowych w obrębie zachodniej krawędzi doliny Odry, na południe od Szczecina (typy gleb oraz skład granulometryczny poziomów genetycznych podano w tab. 1)

According to the division of Szczecin voivodship into climate regions, the study area belongs to VII Goleniów - Pyrzyce land (Koźmiński 1983). It includes Szczecin Lowland and areas located to the west of the Oder. At its centre, there occurs the lowest rainfall, and the highest temperatures apart from Szczecin region. The average temperature for the period 1956-1990 was $8.4^{\circ} \mathrm{C}$, and for vegetation period (April - October) $-13.4^{\circ} \mathrm{C}$. The average annual precipitation for the period was $528 \mathrm{~mm}$, and for the vegetation period $-364 \mathrm{~mm}$. The number of hot days (above $25^{\circ} \mathrm{C}$ ) in the studied area reaches 25 a year. In March, the dry east winds prevail, which causes dryness of the soil. On average, there are 44 days with snow cover in the southern part of the area, and about 100 days with frost. 
Extreme values of some climatic conditions are of great importance to the occurrence of xerothermic communities in the area, especially years of exceptionally low average rainfall repeated periodically, often totalling below $500 \mathrm{~mm}$ in this area. This amount of rainfall is much smaller than the sum which delimits the occurrence of steppes in Eastern Europe. These dry years lead to drying out of a number of mesophilic species, which often successfully take place of xerothermic grasslands in the climatic zone of Pomerania. Then, the ability of grasslands to withstand drought allows the species to survive the critical period that eliminates their competitors. The impact of low rainfall is intensified by strings of days without precipitation, which can exceed 18 days and be repeated up to three times a year, and strings of 9 days can be repeated up to dozen or so times a year. Additionally, the periods of high temperatures, similarly to dry years, reduce the growth of mesophilic species. The influence of temperature is strengthened by winds, especially in spring and summer periods, when they affect southern and south-eastern slopes. Winds intensify evaporation of soil water and increase soil moisture deficiency, which is especially high in summer.

Apart from general climatic conditions on south-eastern and eastern slopes of the study area, the development of xerothermic species is highly influenced by a microclimate formed mainly under the influence of strong insolation. Uncovered slopes are characterized by significantly higher air temperatures and higher moisture deficiency of soils, which makes the habitats very dry and warm, which is favourable to the growth of xerothermic plants. According to our study, the afternoon air temperature on soil surface devoid of vegetation in the central part of the southern slope ranged from 42 to $51^{\circ} \mathrm{C}$. While at the same time, on the western and northern slope it was much lower and ranged from $24-27^{\circ} \mathrm{C}$.

\section{MATERIAL AND METHODS}

The study of plant communities, determining their floristic composition and structure was conducted in the area of western edge of the Western Oder on southern, south-eastern and south-western slopes. A total of 29 phytosociological relevés were made in the first half of July 2010. The nomenclature of the distinguished syntaxa and phytosociological classification of communities was based on the classification by Matuszkiewicz (2007). Papers by Friedrich and Semczyszyn (2002), Prajs (2010), Filipek (1974b) and Jasnowska (1973) were also used. Phytosociological stability (S) and cover coefficients of species (D) were calculated in analytical phytosociological charts with the use of methods described by Dzwonko (2007). The names of the species were given by Mirek et al. (2002). Six soil pits were made within the slopes of southern, south-eastern and south-western exposition in five villages: Kamionka, Kamieniec, Kurów (Fig. 1), Waliszewo (Fig. 2), and Pargowo, in the vicinity of which geobotanical research was conducted (Fig. 3). On the basis of the existing genetic horizons and morphological features of soil within individual soil profiles, soil types were determined using the new Polish Soil Classification 2011 (Marcinek and Komisarek 2011). Soil samples were taken from each genetic horizon in order to be analysed in the laboratory. Their basic parameters were determined. Their $\mathrm{pH}$ values were determined with potentiometric method, and soil $\mathrm{pH}$ in individual horizons was then determined on their basis. The content of $\mathrm{CaCO}_{3}$ was determined with the use of Scheibler's method, and particle size distribution with the use 
of Casagrande's method modified by Prószyński (Koćmit et al. 1981). Apart from six soil pits, 21 collective samples from the depth of $25 \mathrm{~cm}$ were taken from the areas were releve had been made. They were also analysed in terms of basic soil parameters. Tables 2 and 3 include only particle size distribution, while the $\mathrm{pH}$ values in $\mathrm{H}_{2} \mathrm{O}$ and $1 \mathrm{MKCl}$ as well as the content of $\mathrm{CaCO}_{3}$ were similar to soil parameters of $\mathrm{Ak}$ horizon of individual soil pits and therefore were omitted in order not to lengthen the tables.

\section{RESULTS AND DISCUSSION}

The study conducted on the western part of the Oder River valley has shown that glacial sediments are characterized by varied mechanical composition, while there are different types of clay with layers of sands or varved sands. They are usually alkaline due to the constant presence of $\mathrm{CaCO}_{3}$. The vegetation found in these habitats consists mainly of tuft or solon rampantly growing grasses. Despite significant drops of edge slopes, the compact particle size distribution as well as abundant grassy vegetation limit erosion and are beneficial for the accumulation of organic compounds and the development of humus level. However, on some parts of slopes there is frequently lack of humus horizon, especially on sandy soils with poorly compacted grasslands. This is the result of the rapid decomposition of organic matter and it being scattered and washed on steep slopes due to erosion processes.

Deep boulder clay with particle size distribution of sandy and light loams (Pargowo, Kurów, Waliszewo) and medium deep loams underlaid with sand (Kamieniec) developed into typical eutrophic brown soil (BEt). The soils are characterized by neutral reaction in humus horizon and alkaline reaction in browning horizon and bedrock as well as a significant content of $\mathrm{CaCO}_{3}$ (most often below 10\%) - Table 1. Moreover, field studies have revealed that the soil on slopes shows significant local diversity. In the central and southern parts of the study area, loams and sands often occur in the immediate vicinity within the same slope.

Glacial sediments in the gorge near Kamionki are of slightly different character. Sandy sediments were found both on southern (soil pit No. 1) and northern (soil pit No. 2) slopes. Soils poorly formed by erosion (SY) were formed from them in the diagnostic horizons with the particle size distribution of loamy sands, which on various depths transformed into slightly clayey and loose sands (Table 1, Fig. 4). In addition, these soils differ in terms of soil reaction and the content of calcium carbonate depending on slope exposition (Table 1). The lack of calcium carbonate and acidification of humus horizon are significant in soil poorly formed by erosion (SY) on northern slope in comparison to other alkaline and rich in calcium carbonate soils of the western edge of the Oder River.

In the specific habitats of western edge of the Oder Valley, two types of grassland habitats were distinguished - Potentillo-Stipetum capillatae Libb. 1993 em. Krausch 1960 and AdonidoBrachypodietum pinnate (Libb. 1993) Krausch 1960. Stipa grasses (Potentillo-Stipetum) occur in subxerothermic regions of Pomerania, Wielkopolska and Kujawy. Phytocoenoses of this association inhabit areas of extreme topoclimatic conditions i.a. substrates rich in calcium carbonate exposed to the South i.a. in the Lower Oder Valley (Matuszkiewicz 2007). The community of Potentillo-Stipetum capillatae is often described as the Pomeranian stipe steppe (Wysocki i Sikorski 2002). 
Table 1. Mechanical composition and some chemical properties of soil

Tabela 1. Skład granulometryczny oraz niektóre właściwości chemiczne gleb

\begin{tabular}{|c|c|c|c|c|c|c|c|c|}
\hline \multirow{2}{*}{$\begin{array}{l}\text { Locality and location of soil pit } \\
\text { Miejscowość i lokalizacja } \\
\text { odkrywki glebowej }\end{array}$} & \multirow{2}{*}{$\begin{array}{l}\text { Soil horizons, depth } \\
\text { Poziom genetyczny, } \\
\text { miąższość } \\
{[\mathrm{cm}]}\end{array}$} & \multicolumn{3}{|c|}{$\begin{array}{l}\text { Percentage of fractions content } \\
\text { Zawartość frakcji o określonych } \\
\text { wymiarach [mm] }\end{array}$} & \multirow[t]{2}{*}{$\begin{array}{l}\text { Group mechanical composition } \\
\text { Grupa granulometryczna }\end{array}$} & \multicolumn{2}{|c|}{$\mathrm{pH}$} & \multirow[t]{2}{*}{$\begin{array}{c}\mathrm{CaCO}_{3} \\
{[\%]}\end{array}$} \\
\hline & & $2-0.5$ & $0.05-0.002$ & $<0.002$ & & $\mathrm{H}_{2} \mathrm{O}$ & $1 \mathrm{MKCl}$ & \\
\hline 1 & 2 & 3 & 4 & 5 & 6 & 7 & 8 & 9 \\
\hline \multirow{3}{*}{$\begin{array}{c}\text { Edge of the } S \text { - ravine near } \\
\text { Kamionka } \\
\text { Soil pit No. } 1\end{array}$} & \multicolumn{8}{|c|}{$\begin{array}{l}\text { Soils poorly formed by erosion - soil pit No. } 1 \\
\text { Gleba słabo ukształtowana erozyjnie (SY) - odkrywka nr } 1\end{array}$} \\
\hline & Ak1 (0-11) & 83 & 15 & 2 & $\begin{array}{c}\text { loamy sand } \\
\text { piasek gliniasty }(\mathrm{pg})\end{array}$ & 7.78 & 7.26 & 2.1 \\
\hline & Ak2 (11-41) & 86 & 10 & 4 & $\begin{array}{c}\text { loamy sand } \\
\text { piasek gliniasty (pg) }\end{array}$ & 7.80 & 7.46 & 1.2 \\
\hline \multirow{4}{*}{$\begin{array}{c}\text { Zbocze o wystawie } S \text { - wąwóz } \\
\text { w pobliżu Kamionki } \\
\text { Odkrywka nr } 1\end{array}$} & Ck1 (41-71) & 77 & 19 & 4 & $\begin{array}{c}\text { loamy sand } \\
\text { piasek gliniasty }(\mathrm{pg})\end{array}$ & 7.81 & 7.60 & 1.9 \\
\hline & Ck2 (71-116) & 93 & 2 & 5 & $\begin{array}{c}\text { slightly sand } \\
\text { piasek słabogliniasty (ps) }\end{array}$ & 7.81 & 7.28 & 0.4 \\
\hline & Ck3 (116-125) & 95 & 4 & 0 & $\begin{array}{c}\text { loose sand } \\
\text { piasek luźny }(\mathrm{pl})\end{array}$ & 8.37 & 8.02 & 4.7 \\
\hline & Ck4 (125-150) & 90 & 9 & 1 & $\begin{array}{c}\text { slightly sand } \\
\text { piasek słabogliniasty (ps) }\end{array}$ & 8.30 & 8.07 & 12.5 \\
\hline \multirow{5}{*}{$\begin{array}{c}\text { Edge of the } \mathrm{N} \text { - ravine near } \\
\text { Kamionka } \\
\text { Soil pit No. } 2 \\
\text { Zbocze o wystawie } \mathrm{N} \text { - wąwóz } \\
\text { w pobliżu Kamionki } \\
\text { Odkrywka nr } 2\end{array}$} & \multicolumn{8}{|c|}{$\begin{array}{l}\text { Soils poorly formed by erosion - soil pit No. } 2 \\
\text { Gleba słabo ukształtowana erozyjnie (SY) - odkrywka nr } 2\end{array}$} \\
\hline & $A(0-30)$ & 70 & 25 & 5 & $\begin{array}{c}\text { loamy sand } \\
\text { piasek gliniasty }(\mathrm{pg})\end{array}$ & 6.56 & 5.52 & - \\
\hline & $\mathrm{A} / \mathrm{C}(30-45)$ & 79 & 16 & 5 & $\begin{array}{l}\text { loamy sand } \\
\text { piasek gliniasty }(\mathrm{pg})\end{array}$ & 7.39 & 6.60 & - \\
\hline & C1 (45-75) & 94 & 2 & 4 & $\begin{array}{c}\text { loose sand } \\
\text { piasek luźny }(\mathrm{pl})\end{array}$ & 7.70 & 7.39 & 0.4 \\
\hline & C2 (75-150) & 97 & 1 & 2 & $\begin{array}{c}\text { loose sand } \\
\text { piasek luźny(pl) }\end{array}$ & 7.81 & 7.08 & 0.9 \\
\hline \multirow{3}{*}{$\begin{array}{c}\text { Edge of the } S \text { - ravine near } \\
\text { Kamieńca } \\
\text { Soil pit No. } 3\end{array}$} & \multicolumn{8}{|c|}{$\begin{array}{c}\text { Typical eutrophic brown soil - soil pit No. } 3 \\
\text { Gleba brunatna eutroficzna typowa (BEt) - odkrywka nr } 3\end{array}$} \\
\hline & Ak $(0-25)$ & 65 & 27 & 8 & $\begin{array}{c}\text { sandy loam } \\
\text { glina piaszczysta (gp) }\end{array}$ & 7.77 & 7.16 & 5.0 \\
\hline & Ak/Bwk (25-35) & 61 & 30 & 9 & $\begin{array}{l}\text { sandy loam } \\
\text { glina piaszczysta (gp) }\end{array}$ & 7.84 & 7.20 & 6.4 \\
\hline
\end{tabular}


Table 1. Mechanical composition and some chemical properties of soil (cont.)

Tabela 1. Skład granulometryczny oraz niektóre właściwości chemiczne gleb (cd.)

\begin{tabular}{|c|c|c|c|c|c|c|c|c|}
\hline 1 & 2 & 3 & 4 & 5 & 6 & 7 & 8 & 9 \\
\hline \multirow{3}{*}{$\begin{array}{c}\text { Zbocze o wystawie S - wąwóz } \\
\text { w pobliżu Kamieńca } \\
\text { Odkrywka nr } 3\end{array}$} & Bwk (35-60) & 68 & 28 & 4 & $\begin{array}{c}\text { sandy loam } \\
\text { glina piaszczysta (gp) }\end{array}$ & 7.70 & 7.48 & 5.4 \\
\hline & Bwk/Ck (60-75) & 95 & 2 & 3 & $\begin{array}{l}\text { loose sand } \\
\text { piasek luźny(pl) }\end{array}$ & 7.89 & 7.87 & 3.2 \\
\hline & Ck (75-150) & 98 & 2 & 0 & $\begin{array}{l}\text { loose sand } \\
\text { piasek luźny(pl) }\end{array}$ & 7.98 & 7.91 & 2.1 \\
\hline \multirow{6}{*}{$\begin{array}{l}\text { Natural exposition of the slope } \\
\text { of the SW in Kurów } \\
\text { Soil pit No. } 4 \\
\text { Naturalne odsłonięcie zbocza } \\
\text { o wystawie SW w Kurowie } \\
\text { Odkrywka nr } 4\end{array}$} & \multicolumn{8}{|c|}{$\begin{array}{l}\text { Typical eutrophic brown soil - soil pit No. } 4 \\
\text { Gleba brunatna eutroficzna typowa (BEt) - odkrywka nr } 4\end{array}$} \\
\hline & Ak (0-20) & 69 & 24 & 7 & $\begin{array}{c}\text { sandy loam } \\
\text { glina piaszczysta (gp) }\end{array}$ & 7.62 & 7.18 & 5.3 \\
\hline & Ak/Bwk (20-25) & 67 & 27 & 7 & $\begin{array}{l}\text { light loam } \\
\text { glina lekka (gl) }\end{array}$ & 7.53 & 7.40 & 5.6 \\
\hline & Bwk (25-65) & 62 & 29 & 9 & $\begin{array}{c}\text { light loam } \\
\text { glina lekka }(\mathrm{gl})\end{array}$ & 7.82 & 7.42 & 7.8 \\
\hline & Ck1 (65-85) & 56 & 33 & 11 & $\begin{array}{c}\text { light loam } \\
\text { glina lekka }(\mathrm{gl})\end{array}$ & 7.81 & 7.46 & 11.9 \\
\hline & Ck2 (85-150) & 54 & 37 & 9 & $\begin{array}{l}\text { light loam } \\
\text { glina lekka }(\mathrm{gl})\end{array}$ & 7.91 & 7.40 & 9.2 \\
\hline \multirow{5}{*}{$\begin{array}{c}\text { Natural exposition of the slope } \\
\text { of the S in Waliszewo } \\
\text { Soil pit No. } 5 \\
\text { Naturalne odsłonięcie zbocza } \\
\text { o wystawie S w Waliszewie } \\
\text { Odkrywka nr } 5\end{array}$} & \multicolumn{8}{|c|}{$\begin{array}{l}\text { Typical eutrophic brown soil - soil pit No. } 5 \\
\text { a brunatna eutroficzna typowa (BEt) - odkrywka nr } 5\end{array}$} \\
\hline & Ak $(0-25)$ & 54 & 35 & 11 & $\begin{array}{c}\text { light loam } \\
\text { glina lekka }(\mathrm{gl})\end{array}$ & 7.74 & 7.41 & 8.4 \\
\hline & Ak/Bwk (25-45) & 24 & 65 & 11 & $\begin{array}{c}\text { silt loam } \\
\text { pył gliniasty (pyg) }\end{array}$ & 7.79 & 7.39 & 7.5 \\
\hline & Bwk (45-61) & 55 & 40 & 5 & $\begin{array}{c}\text { sandy loam } \\
\text { glina piaszczysta (gp) }\end{array}$ & 7.95 & 7.51 & 2.5 \\
\hline & Ck (61-150) & 60 & 24 & 16 & $\begin{array}{l}\text { light loam } \\
\text { glina lekka }(\mathrm{gl})\end{array}$ & 7.85 & 7.62 & 8.8 \\
\hline \multirow{4}{*}{$\begin{array}{l}\text { Edge of the SE in Progów } \\
\text { Soil pit No. } 6\end{array}$} & \multicolumn{8}{|c|}{$\begin{array}{l}\text { Typical eutrophic brown soil - soil pit No. } 6 \\
\text { Gleba brunatna eutroficzna typowa (BEt) - odkrywka nr } 6\end{array}$} \\
\hline & Ak $(0-30)$ & 59 & 30 & 11 & $\begin{array}{c}\text { light loam } \\
\text { glina lekka (gl) }\end{array}$ & 7.51 & 7.20 & 8.1 \\
\hline & Bwk (30-60) & 55 & 35 & 10 & $\begin{array}{c}\text { light loam } \\
\text { glina lekka }(\mathrm{gl})\end{array}$ & 7.72 & 7.38 & 14.3 \\
\hline & Ck (60-150) & 60 & 30 & 10 & $\begin{array}{c}\text { light loam } \\
\text { glina lekka }(\mathrm{gl})\end{array}$ & 8.06 & 7.41 & 11.9 \\
\hline
\end{tabular}


The phytocoenoses of Adonido-Brachypodietum pinnate community form compact grasslands dominated by grasses with numerous perennial dicotyledons. They are found on rendzinas, pararendzinas and soils like chernozem on dry sunny slopes and fallow lands. On a local scale, they occupy less extreme habitats than the communities of Festuco-Stipion alliance. Cirsio-Brachypodion pinnati grasslands are usually semi-natural communities, sustaining due to extensive grazing and transforming gradually into scrub and forest communities after abandoned grazing (Matuszkiewicz 2007).

\section{The community of Potentillo-Stipetum capillatae Libb. $1993 \mathrm{em}$. Krausch 1960 (Table 2)}

Stipa grassland (Table 2) is found on steep slopes (from 25 to $40^{\circ}$ ) of southern, southeastern and south-western exposition. The habitats are very dry and warm. The soil is alkaline through the whole soil profile (soil pit No. 1, Table 1). Humus horizons are well formed and reach the depth from 15 to $25 \mathrm{~cm}$. Phytocoenoses of Potentillo-Stipetum capillatae have the features of steppe vegetation and are found in the lower part of the Oder River including its western edge from Pargowo to Ustowo (Fig. 1). Phytocoenoses of Potentillo-Stipetum capillatae association (14 patches) were recorded in the study area mainly in Kamieniec Gorge and near Kamionka hamlet. Single patches were also found in the vicinity of the villages Moczyły, Kurów and Pargowo (Table 2).

The floristic structure of the association is formed by 137 plant species. The patches are floristically rich and despite significant density $-91.1 \%$, the number of species ranges from 21 to 73 taxa, 53 on average per relevé (Table 2). Potentillo-Stipetum capillatae is a tuft grass. It is dominated by narrowleaf grasses: Stipa capillata $(S=V, D=1393)-$ Fig. 5, Bromus inermis ( $\mathrm{S}=\mathrm{IV}, \mathrm{D}=479)$, Phleum phleoides $(\mathrm{S}=\mathrm{V}, \mathrm{D}=700)$ and Poa compressa $(\mathrm{S}=\mathrm{IV}, \mathrm{D}=361)$ with a number of dicotyledonous species. Five species have a significant share in the phytocoenoses of the association within Festucetalia valesiacae: Potentilla arenaria $(S=V, D=911)$, Anthemis tinctoria ( $=$ IV , D = 546), Bromus inermis ( $=I V, D=479$ ) and Campanula sibirica ( $=$ IV, $D=150)$. The presence of Asparagus officinalis ( $S=I I I, D=193)$ was recorded less frequently.

Festuco-Brometea was characterized by much more taxa (38 species). The most common and most numerous are: Fragaria viridis $(S=V, D=807)$, Salvia pratensis $(S=V, D=729)$, Agrimonia eupatoria $(S=V, D=611)$, Artemisia campestris $(S=V, D=436)$. Other stable components are: Centaurea stoebe ( $=$ IV, $\mathrm{D}=604)$, C. scabiosa ( $=$ IV , D = 382), Dianthus carthusianorum ( $=\mathrm{IV}, \mathrm{D}=214$ ), Euphorbia cyparissias ( $=\mathrm{IV}, \mathrm{D}=239$ ), Veronica spicata $(S=I V, D=857)$, Gentiana cruciata $(S=I V, D=382)-$ Fig. 6 , Sanguisorba minor (S = IV, $D=268)$, Galium verum ( $=$ IV,$D=296)$ and Medicago falcata $(S=I V, D=384)$. Carlina vulgaris ( $\mathrm{S}=\mathrm{IV}, \mathrm{D}=109)$ and Allium oleraceum $(S=I V, D=100)$ were recorded quite often, but with much smaller cover coefficients. Thanks to loose distribution of grass tufts, dicotyledons can develop in the community.

Some patches are often inhabited, however not too numerously, by characteristic species such as Koelerio glaucae-Corynephoretea canescentis: Sedum acre ( $\mathrm{S}=\mathrm{V}, \mathrm{D}=582)$, Festuca ovina ( $=$ IV, D = 450), Helichrysum arenarium ( $=$ IV, $D=221)$ and slightly less often by (S = III) Trifolium arvense, Artemisia maritima subsp. elongata and Solidago virgaurea. The concentration in these phytocoenoses of species characteristic for sandy grasslands is due to habitat conditions. Some soils in the study area are loamy sand, slightly clayey sand and loose sand of alkaline reaction and with a significant content of calcium carbonate (from 2.2 to $12.5 \%$ ) - Table 1 . 
Table. 2. Stipa grass Potentillo-Stipetum capillatae Libb. 1933 em. Krausch 1960. Variant with characteristic species Rhamno-Prunetea (relevés 1-5), typical variant (relevés 6-14)

Tabela. 2. Murawa ostnicowa Potentillo-Stipetum capillatae Libb. 1933 em. Krausch 1960. Wariant z gatunkami charakterystycznymi Rhamno-Prunetea (zdjęcia 1-5), wariant typowy (zdjęcia 6-14)

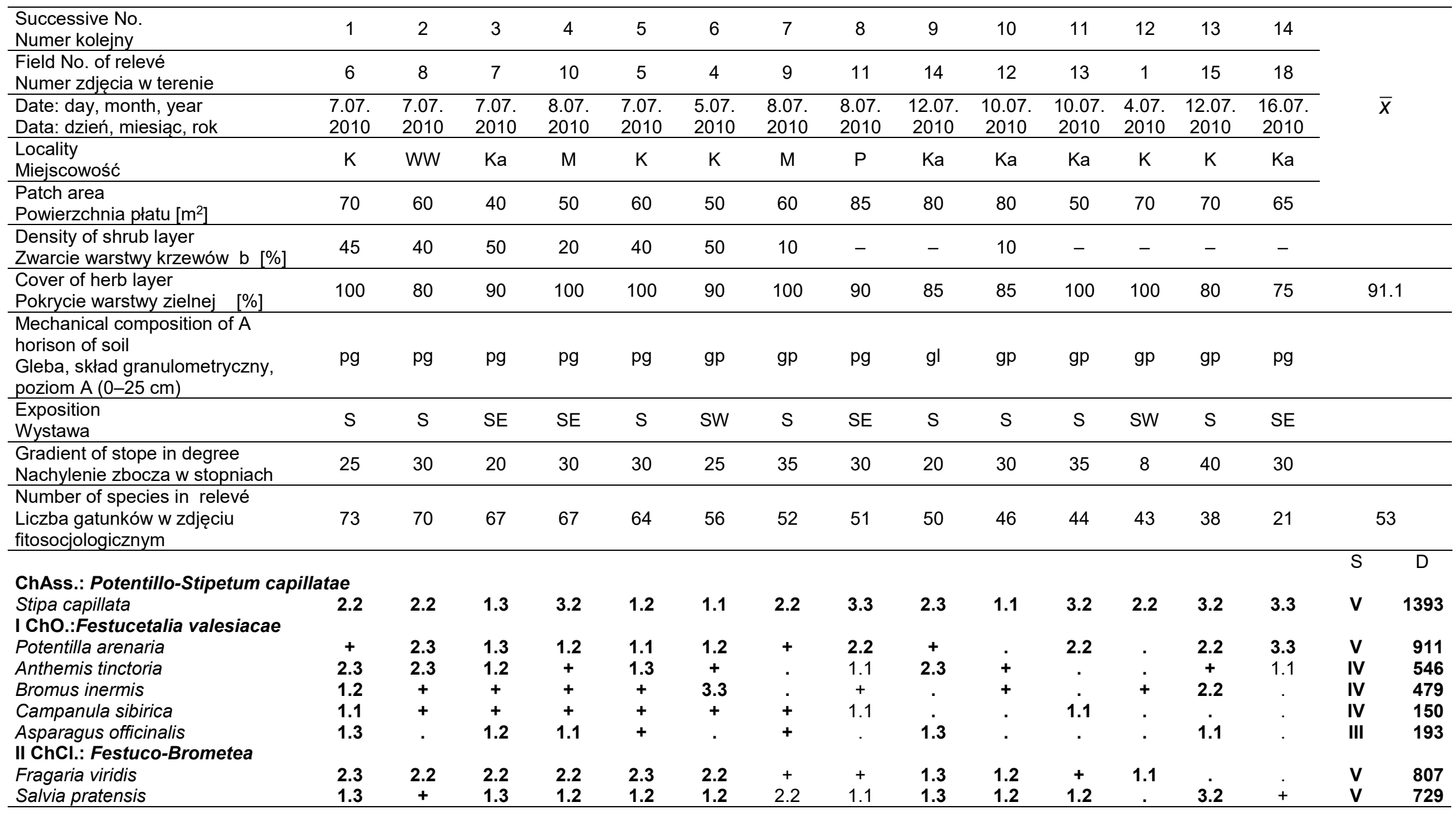


Table. 2. Stipa grass Potentillo-Stipetum capillatae Libb. 1933 em. Krausch 1960. Variant with characteristic species Rhamno-Prunetea (relevés 1-5), typical variant (relevés 6-14) (cont.)

Tabela. 2. Murawa ostnicowa Potentillo-Stipetum capillatae Libb. 1933 em. Krausch 1960. Wariant z gatunkami charakterystycznymi Rhamno-Prunetea (zdjęcia 1-5), wariant typowy (zdjęcia 6-14) (cd.)

\begin{tabular}{|c|c|c|c|c|c|c|c|c|c|c|c|c|c|c|c|c|}
\hline Phleum phleoides & 2.3 & 1.2 & 2.2 & 1.2 & 2.3 & + & + & 1.1 & & 1.2 & 1.2 & & 2.2 & + & $\mathbf{V}$ & 700 \\
\hline Agrimonia eupatoria & 1.3 & 1.2 & 1.2 & 1.1 & 1.1 & 1.2 & + & . & 1.3 & 1.1 & + & 3.3 & 1.2 & + & V & 611 \\
\hline Artemisia campestris & 1.3 & 1.2 & 2.3 & + & + & + & + & + & 1.3 & 1.2 & + & . & 2.2 & & V & 436 \\
\hline Veronica spicata & 2.3 & 2.2 & 2.2 & 1.1 & 1.3 & 2.2 & . & 2.2 & & + & . & . & 1.1 & 2.2 & IV & 857 \\
\hline Centaurea stoebe & 2.3 & 2.2 & 1.2 & + & 1.2 & + & . & 1.1 & 2.3 & 1.2 & . & . & 1.1 & 1.1 & IV & 604 \\
\hline Centaurea scabiosa & 1.3 & + & 1.2 & 1.1 & 2.3 & 1.3 & . & 1.1 & & 1.1 & . & 1.3 & . & . & IV & 382 \\
\hline Gentiana cruciata & 1.3 & . & 1.2 & 1.1 & 1.3 & . & + & . & 1.3 & . & 1.1 & 2.3 & 1.1 & . & IV & 382 \\
\hline Poa compressa & + & 1.2 & . & . & 1.1 & . & + & 1.1 & 1.3 & 1.2 & 2.2 & 1.2 & + & & IV & 361 \\
\hline Medicago falcata & + & . & + & 2.2 & . & + & + & 1.1 & + & 1.2 & . & 1.3 & . & 1.1 & IV & 304 \\
\hline Galium verum & + & 1.3 & . & 2.2 & 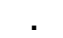 & + & + & 1.1 & 1.3 & . & 1.3 & . & . & + & IV & 296 \\
\hline Sanguisorba minor & + & 1.1 & + & + & + & 1.2 & . & 1.1 & 2.3 & + & . & . & . & & IV & 268 \\
\hline Euphorbia cyparissias & . & + & + & + & + & 1.1 & . & 1.1 & . & + & + & . & 1.2 & 2.2 & IV & 239 \\
\hline Dianthus carthusianorum & + & 1.2 & 1.1 & 1.2 & + & + & . & 3.3 & + & 1.1 & . & . & 1.2 & + & IV & 214 \\
\hline Carlina vulgaris & + & + & + & + & + & + & + & + & . & . & + & + & . & 1.1 & IV & 107 \\
\hline Allium oleraceum & + & 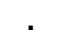 & + & + & & + & . & + & + & 1.1 & + & + & + & . & IV & 100 \\
\hline Acinos arvensis & 1.1 & 2.2 & 1.2 & . & 1.1 & . & + & 1.1 & 1.1 & . & . & + & . & . & III & 318 \\
\hline Astragalus glycyphyllos & 1.3 & 1.2 & 1.3 & 2.2 & 1.3 & 1.2 & . & + & + & . & . & . & . & . & III & 318 \\
\hline Melampyrum arvense & + & 1.2 & . & 1.2 & 1.2 & + & 2.2 & . & . & . & 1.2 & . & + & . & III & 289 \\
\hline Brachypodium pinnatum & . & 1.2 & + & . & + & 1.2 & + & + & . & + & 1.2 & . & . & . & III & 143 \\
\hline $\begin{array}{l}\text { Anthyllis vulneraria subsp. } \\
\text { polyphylla }\end{array}$ & + & + & . & 1.1 & . & . & - & 1.1 & . & . & + & + & . & . & III & 100 \\
\hline Petrorhagia prolifera & + & + & + & 1.1 & + & . & + & . & + & . & . & + & . & . & III & 86 \\
\hline Hieracium echioides & . & . & 1.2 & 1.2 & + & + & . & + & . & . & . & . & . & . & II & 93 \\
\hline Prunella grandiflora & . & + & . & 1.1 & . & . & + & + & . & . & 1.2 & . & . & . & II & 93 \\
\hline Ajuga genevensis & + & . & . & 1.1 & . & . & . & + & . & . & 1.1 & . & . & . & II & 86 \\
\hline Plantago media & + & + & . & 1.2 & . & . & . & + & . & . & . & + & . & . & II & 64 \\
\hline Stachys recta & . & + & . & . & . & . & + & . & . & . & 1.2 & . & + & . & II & 57 \\
\hline Koeleria pyramidata & . & . & . & . & . & + & 1.1 & + & . & . & . & . & + & . & II & 57 \\
\hline Trifolium montanum & + & . & . & . & . & . & + & . & . & + & + & . & . & . & II & 29 \\
\hline \multicolumn{17}{|c|}{ III ChCl.: Artemisietea vulgaris } \\
\hline Hypericum perforatum & 1.3 & + & 1.1 & + & 1.3 & + & + & . & 1.3 & + & . & + & . & . & IV & 186 \\
\hline Rubus caesius & 3.4 & . & 2.3 & . & 3.3 & 2.3 & . & . & 2.3 & 2.3 & . & . & + & . & III & 1043 \\
\hline Picris hieracioides & 1.1 & 2.2 & 1.2 & . & 1.3 & . & . & . & 1.3 & & . & 1.2 & + & . & III & 311 \\
\hline Melilotus alba & 2.3 & . & + & . & + & . & . & . & + & + & 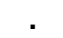 & 1.2 & + & . & III & 196 \\
\hline Echium vulgare & 1.3 & 1.2 & . & . & . & 1.2 & + & + & . & . & 1.2 & . & + & . & III & 164 \\
\hline Epilobium montanum & 1.3 & . & + & . & 1.2 & + & . & . & 1.3 & . & . & 1.2 & + & . & III & 164 \\
\hline Artemisia vulgaris & + & . & + & 1.1 & + & 1.3 & . & . & . & 1.1 & . & . & . & . & III & 129 \\
\hline Medicago Iupulina & + & 1.1 & + & + & + & . & . & & 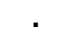 & + & . & . & . & 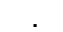 & III & 71 \\
\hline
\end{tabular}


Table. 2. Stipa grass Potentillo-Stipetum capillatae Libb. 1933 em. Krausch 1960. Variant with characteristic species Rhamno-Prunetea (relevés 1-5), typical variant (relevés 6-14) (cont.)

Tabela. 2. Murawa ostnicowa Potentillo-Stipetum capillatae Libb. 1933 em. Krausch 1960. Wariant z gatunkami charakterystycznymi Rhamno-Prunetea (zdjęcia 1-5), wariant typowy (zdjęcia 6-14) (cd.)

Cynoglossum officinale Melilotus officinalis

Cichorium intybus

Melandrium album

Veronica chamaedrys

Oenothera biennis

IV ChCl:: Molinio-Arrhenatheretea

Arrhenatherum elatius

Galium mollugo

Dactylis glomerat

Knautia arvensis

Achillea millefolium

Festuca rubra

Pimpinella saxifraga

Daucus carota

Plantago lanceolata

Tragopogon pratensis

Centaurea jacea

Lothus corniculatus

Rumex acetosa

V ChCl.: Koelerio glaucae-Corynephoretea canescentis

\section{Festuca ovina}

Helichrysum arenarium

Solidago virgaurea

Trifolium arvense

Armeria maritima subsp. elongata

Thymus pulegioides

Trifolium campestre

Agrostis capillaris

Senecio vernalis

VI ChCl: Epilobietea angustifoliae

Calamagrostis epigejos

Betula pendula

b 1.2

$\begin{array}{ccc}2.2 & 1.1 & 2.3 \\ 1.3 & + & 2.2\end{array}$

1.3

$+$

Falcaria vulgaris

1.2

pentis

$\begin{array}{cccc}2.3 & . & 2.3 & + \\ 1.3 & 2.2 & 1.2 & . \\ 1.2 & 1.2 & + & 1.2 \\ 1.3 & + & 1.2 & + \\ + & + & + & . \\ 3.3 & 2.3 & 2.3 & . \\ 1.3 & . & + & 1.1 \\ + & + & + & . \\ + & . & . & 1.1 \\ + & + & . & + \\ . & . & . & 1.2 \\ . & . & . & 1.2\end{array}$

$\begin{array}{ccc}+ & \\ + & \\ & + \\ & + \\ & \cdot \\ & \cdot \\ & \\ & 2.3 \\ & 1.2 \\ 2 & 1.3 \\ & 1.3 \\ & 1.3 \\ & 2.3 \\ 1 & + \\ 1 & 1.3 \\ + & + \\ 2 & . \\ & + \\ & +\end{array}$

\begin{tabular}{|c|c|c|c|c|c|c|c|}
\hline & + & . & . & + & + & . & . \\
\hline 1.1 & . & . & & . & 1.2 & . & . \\
\hline . & + & . & 1.1 & . & . & . & . \\
\hline . & . & . & 1.1 & . & . & . & . \\
\hline+ & . & : & $\cdot$ & + & . & . & . \\
\hline . & . & + & . & . & . & . & . \\
\hline
\end{tabular}

71
86
57
50
29
21

$22 \quad 12 \quad 11$

.3

.2

3$$
1.3
$$$$
+
$$$$
\begin{aligned}
& 1.2 \\
& 1.1
\end{aligned}
$$

$2.3+$
$+\quad 1.2$

964 
Table. 2. Stipa grass Potentillo-Stipetum capillatae Libb. 1933 em. Krausch 1960. Variant with characteristic species Rhamno-Prunetea (relevés 1-5), typical variant (relevés 6-14) (cont.)

Tabela. 2. Murawa ostnicowa Potentillo-Stipetum capillatae Libb. 1933 em. Krausch 1960. Wariant z gatunkami charakterystycznymi Rhamno-Prunetea (zdjęcia 1-5), wariant typowy (zdjęcia 6-14) (cd.)

\begin{tabular}{|c|c|c|c|c|c|c|c|c|c|c|c|c|c|c|c|c|}
\hline \multirow{2}{*}{$\begin{array}{l}\text { Equisetum arvense } \\
\text { Convolvulus arvensis } \\
\text { VIII ChCl.: Rhamno-Prunetea }\end{array}$} & . & + & . & + & . & + & . & . & . & . & . & + & . & . & II & 29 \\
\hline & + & . & . & . & . & . & . & + & . & + & . & . & . & . & II & 21 \\
\hline Crategus mongyna $\quad \mathrm{b}$ & 2.3 & 3.2 & 1.1 & + & 2.2 & . & . & . & . & 1.2 & . & . & . & . & III & 596 \\
\hline Rosa canina & 2.3 & . & 2.2 & + & 1.1 & 1.1 & . & . & . & . & . & . & . & . & II & 286 \\
\hline Prunus spinosa & 1.3 & 2.2 & & 1.1 & 1.2 & . & 1.1 & . & . & . & . & . & . & . & II & 268 \\
\hline Euonymus europaea b & . & 1.1 & 1.2 & + & . & . & . & . & . & . & . & . & . & . & II & 79 \\
\hline \multicolumn{17}{|l|}{ IX ChCl.: Stellarietea mediae } \\
\hline Vicia tetrasperma & + & 1.1 & + & . & + & + & . & . & . & . & . & . & . & . & II & 64 \\
\hline Conyza canadensis & + & . & + & . & . & . & . & . & + & . & . & . & . & . & II & 21 \\
\hline \multicolumn{16}{|c|}{ X ChCl.: Trifolio-Geranietea sanguinei } & 21 \\
\hline Origanum vulgare & . & . & . & . & . & + & 1.1 & . & 1.1 & . & + & 2.3 & 1.1 & + & III & 254 \\
\hline Thalictrum minus & 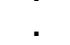 & & . & + & & . & 1.1 & + & 1.2 & + & . & + & + & . & III & 107 \\
\hline Vicia tenuifolia & 1.3 & 1.2 & . & . & 1.2 & . & . & . & . & . & . & . & . & . & II & 107 \\
\hline Verbascum lychnitis & + & . & . & . & . & . & + & . & . & . & + & . & . & . & II & 21 \\
\hline $\begin{array}{l}\text { Campanula rapunculoides } \\
\text { XI ChCl.: Nardo-Callunetea }\end{array}$ & . & . & . & + & . & . & . & . & + & . & . & + & . & . & II & 21 \\
\hline Hieracium pilosella & 1.2 & . & 1.2 & & 1.1 & . & 1.1 & + & . & . & . & . & . & 1.1 & III & 186 \\
\hline $\begin{array}{l}\text { Lupinus polyphyllus } \\
\text { XII Accompanying species - }\end{array}$ & \multicolumn{15}{|c|}{ XII Accompanying species - Gatunki towarzyszące } & 79 \\
\hline Ononis spinosa & + & . & . & + & . & 1.3 & + & . & . & . & + & 1.3 & . & . & III & 100 \\
\hline Senecio jacobaea & + & . & . & + & + & + & . & . & . & + & . & + & 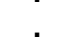 & . & III & 43 \\
\hline Festuca trachyphylla & & & & . & & + & 2.2 & . & . & . & 1.1 & . & 1.1 & + & II & 175 \\
\hline Quercus robur & + & 1.1 & 1.1 & . & 1.1 & . & . & . & . & . & . & . & . & . & II & 114 \\
\hline Myosotis stricta & . & + & . & . & + & . & + & . & . & . & 1.1 & . & + & . & II & 64 \\
\hline Arenaria serpyllifolia & + & + & . & + & . & . & . & + & . & . & . & . & . & . & II & 29 \\
\hline Camelina microcarpa & + & . & . & . & . & . & . & . & . & + & + & . & + & . & II & 29 \\
\hline
\end{tabular}

Plant species occurring only in I degree of relevé constance in plant communities. After a name of species the number of the relevé in which species occurred is given and in brackets the quantity degrees and sociability - Gatunki roślin występujące w zbiorowisku wyłącznie w I stopniu stałości (S). Po nazwie gatunku podano numery zdjęć fitosocjologicznych, w których wystąpił gatunek, w nawiasach - stopnie ilościowości i towarzyskości. Explanations - Objaśnienia: $S$ - phytosociological stability - stałość fitosocjologiczna, D - cover coefficient - współczynnik pokrycia, $\bar{x}$ - medium value - wartości średnie, locality - miejscowości: K - Kamionka, Ka - Kamieniec, M - Moczyły, P - Pargowo, WW - reserve „Wzgórze Widokowe”- rezerwat „Wzgórze Widokowe”.

II: Achillea pannonica 2,4(+); Arabis hirsuta 3(+); Carex praecox 7(+); Filipendula vulgaris 2,8(+); Koeleria macrantha 7(+); Scabiosa columbaria 8,13(+); Seseili annuum 4(+); III: Artemisia absinthium 4,9(+); Geum urbanum 11(+); Helianthus tuberosus 10(1.2); Urtica dioica 10(+); IV: Avenula pubescens 11,13(+); Bromus hordeaceus 2(+); B. tectorum 13(+); Carex hirta 2,9(+); Phleum pratense 9(1.3); Poa pratensis $9(+), 10(1.2)$; Prunella vulgaris 1,5(+); Stellaria graminea $7(+) ;$ Taraxacum officinale 2,3(+); Trifolium pratense $4,7(+)$; T. repens 2(+); Vicia cracca 2(1.2); V: Chondrilla juncea 13(+); Erophila verna 8(+); Thymus serpyllum 13(+); VIII: Ligustrum vulgare b 1(2.3), 12(1.2): IX: Anagallis arvensis 3(+); Geranium pusillum 2(+); Lathyrus tuberosus 10(1.2); Papaver dubium 8(+); Vicia hirsuta 3(+); V. villosa 10(1.1); X: Trifolium medium 9(+); XII: Torilis japonica 5(+); Erigeron acris 3(+); Ranunculus bulbosus $8(+)$. 


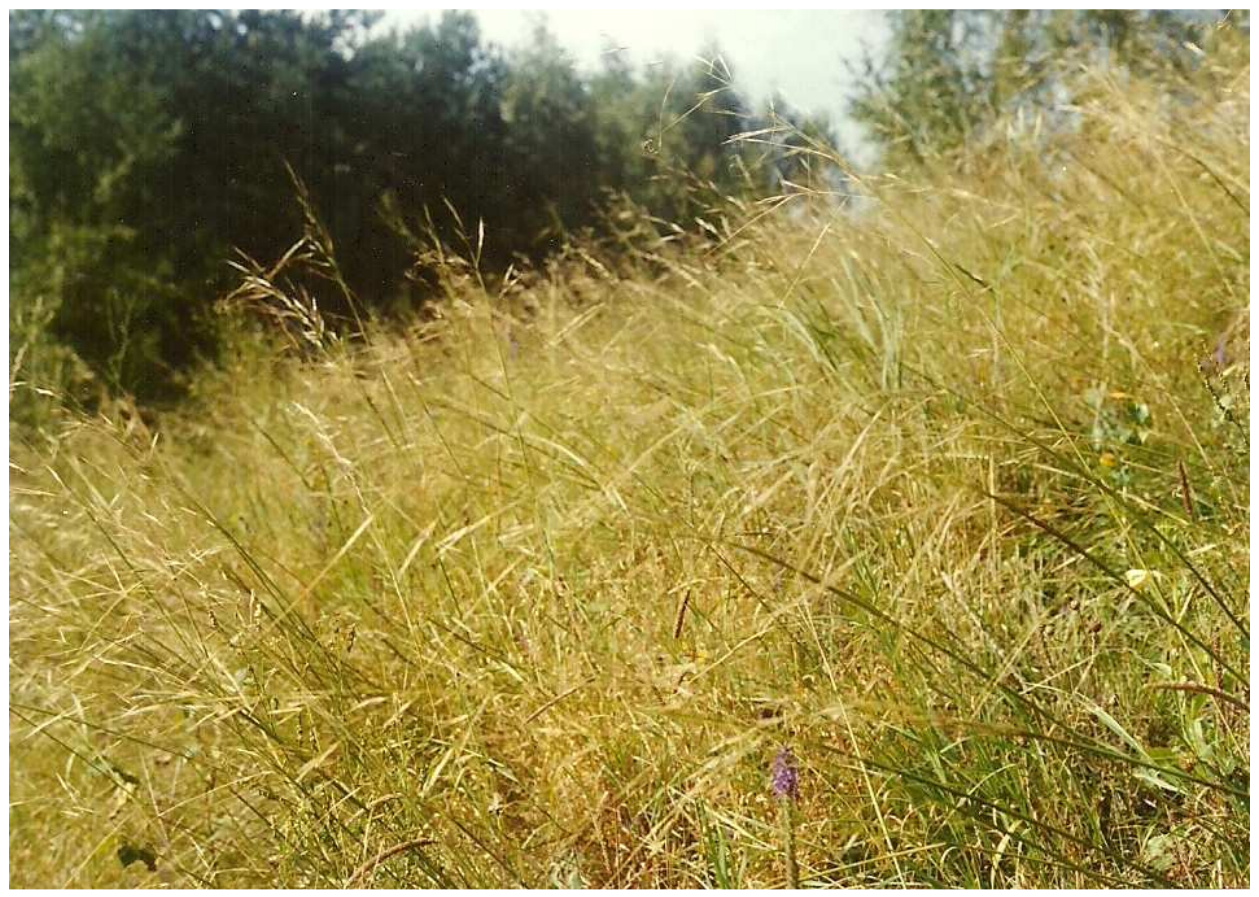

Fig. 5. Turf steppe with stipa capillata (Stipa capillata) on the southern slope of the ravine near the Kamionka (photo I. Kutyna)

Ryc. 5. Murawa stepowa z ostnicą włosowatą (Stipa capillata) na zboczu południowym wąwozu w pobliżu Kamionki (fot. I. Kutyna)

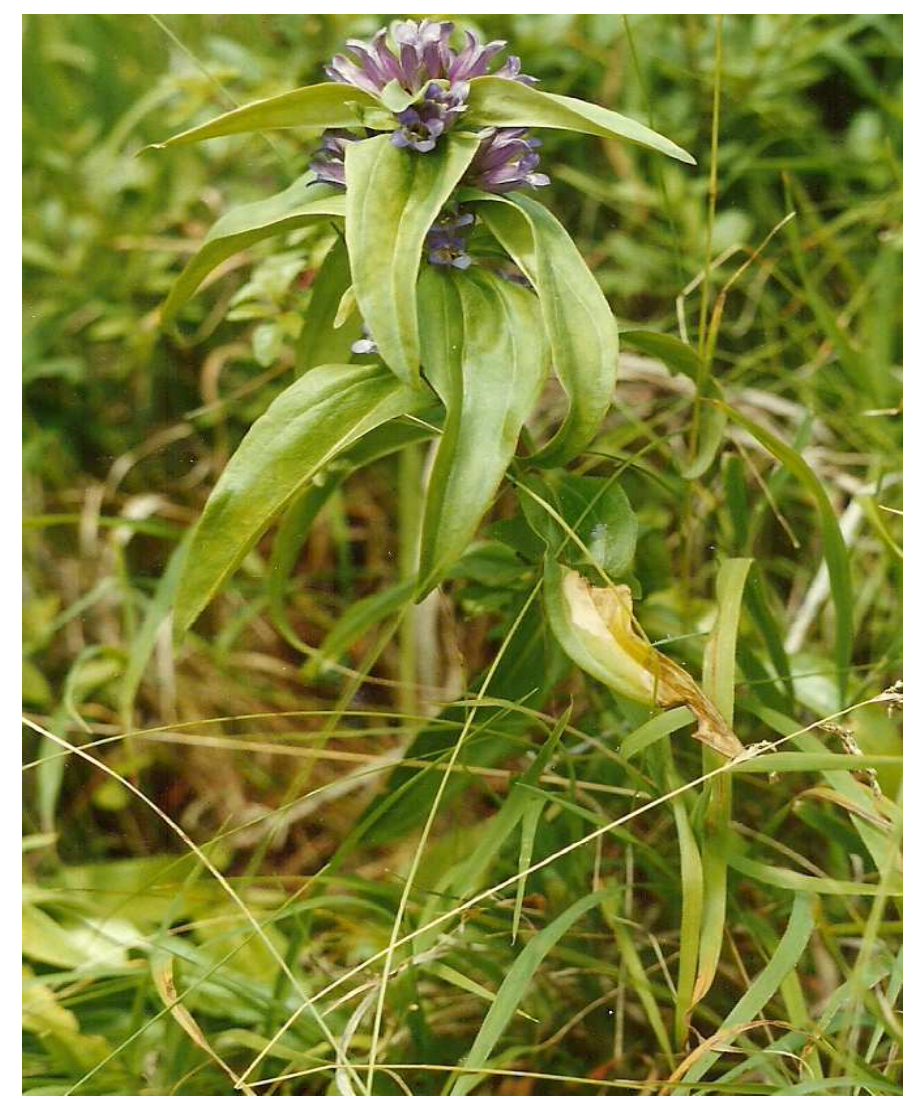

Fig. 6. Star gentian (Gentiana cruciata) - characteristic species of Adonido-Brachypodietum pinnati (photo I. Kutyna)

Ryc. 6. Goryczka krzyżowa (Gentiana cruciata) - gatunek charakterystyczny Adonido-Brachypodietum pinnati (fot. I. Kutyna) 
Some phytocoenoses (relevés from 1 to 5 ) within the association are inhabited by scrub species of Rhamno-Prunetea. This fragment of syntaxon was included into the variant with the participation of species characteristic of this class. Layer b of the community is inhabited most numerously. The lack of human exploitation (grazing, mowing) of this area leads to the disappearance of xerothermic grasslands in the process of succession. The invasive inflow of scrub and forest communities, as well as to a lesser degree ruderal communities, can be observed in some patches.

The unfavourable phenomenon within the association is the increasing and dominant participation of meadow grasses, especially Arrhenatherum elatius ( $\mathrm{S}=\mathrm{IV}, \mathrm{D}=964)$ and Dactylis glomerata ( $=\mathrm{IV}, \mathrm{D}=293$ ) as well as dicotyledons: Galium mollugo ( $=\mathrm{IV}, \mathrm{D}=382$ ), Knautia arvensis ( $\mathrm{S}=\mathrm{IV}, \mathrm{D}=293$ ), Achillea millefolium ( $=\mathrm{IV}, \mathrm{D}=164)$, and also scrub species Crataegus monogyna $(S=I I I, D=596)$, Prunus spinosa $(S=I I, D=268)$ and Rosa canina $(S=I I, D=286)-$ Table 2 . They eliminate a number of xerothermic species and change the physiognomy of the plant community.

The transformation of xerothermic grassland is made by synanthropic species of Artemisietea vulgaris class (16 taxa). Rubus caesius ( $\mathrm{S}=\mathrm{III}, \mathrm{D}=1043$ ) is found often and numerously both in the patches of typical variant and the variant with the species of Rhamno-Prunetea. In addition, Picris hieracioides ( $=\mathrm{III}, \mathrm{D}=311$ ) and Hypericum perforatum ( $=\mathrm{IV}, \mathrm{D}=186)$ are observed frequently ( $\mathrm{S}=\mathrm{III}$ ) and numerously - Table 2. Quite frequent, but less numerous are also: Medicago lupulina, Artemisia vulgaris, Echium vulgare, Melilotus alba, Epilobium montanum and Cynoglossum officinale (Table 2).

Phytocoenoses of this association are also found in the area of the right bank of the Oder in Owczary (Kutyna et al. 2011, 2012) as well as in Cedynia and within Bielinek reserve (Friedrich and Semczyszyn 2002). The patches of the association from Owczary are characterized by a larger number of characteristic species in comparison to the vegetation found on the left bank of the Oder, from Pargowo to Ustowo. The area of Owczary (Kutyna et al. 2011, 2012) is inhabited by: Anthericum liliago ( $\mathrm{S}=\mathrm{III}, \mathrm{D}=289$ ), Oxytropis pilosa ( $\mathrm{S}=\mathrm{III}$, $D=207$ ), and Alyssum montanum ( $S=I I, D=150$ ). In the area of Cedynia and Bielinek reserve, the species were not recorded by Friedrich and Semczyszyn (2002), as in the case of the left edge of the Oder (from Pargowo to Ustowo).

\section{The associacion of Adonido-Brachypodietum pinnati (Libb 1933) Krausch 1960 (Table 3)}

Adonido-Brachypodietum pinnati community is floristically poorer than locally vicarious Thalictro-Salvietum. In comparison to Potentillo-Stipetum found in the same area, the association occurs in habitats that are more fertile and less extreme in terms of microclimate (Matuszkiewicz 2007). The phytocoenoses of the association form dense grasslands with the dominance of grass. The semi-natural communities of Cirsio-Brachypodion association are preserved due to extensive grazing. At the moment of its abandonment, they gradually transform into scrub and forest communities. Adonido-Brachypodietum pinnati association is a grassy, swarded meadow due to the dominance of tor-grass (Brachypodium pinnatum) $-\mathrm{S}=\mathrm{V}$, $D=3550$ (Table 3). It is found on slopes of varying expositions and inclinations (from $15^{\circ}$ to $40^{\circ}$ ), on soils more fertile then patches of Potentillo-Stipetum capillatae. Clayey soils and clayey silty soils are characterized by well-formed humus horizon, alkaline reaction $(\mathrm{pH}$ in $1 \mathrm{M} \mathrm{KCl}$ ranges from 7.16 to 7.40 ) and the content of $\mathrm{CaCO}_{3}$ from 5.0 to $8.4 \%$ (Table 1). 
Table. 3. Adonido-Brachypodietum pinnati (Libb. 1933), Krausch 1960

Tabela. 3. Adonido-Brachypodietum pinnati (Libb. 1933), Krausch 1960

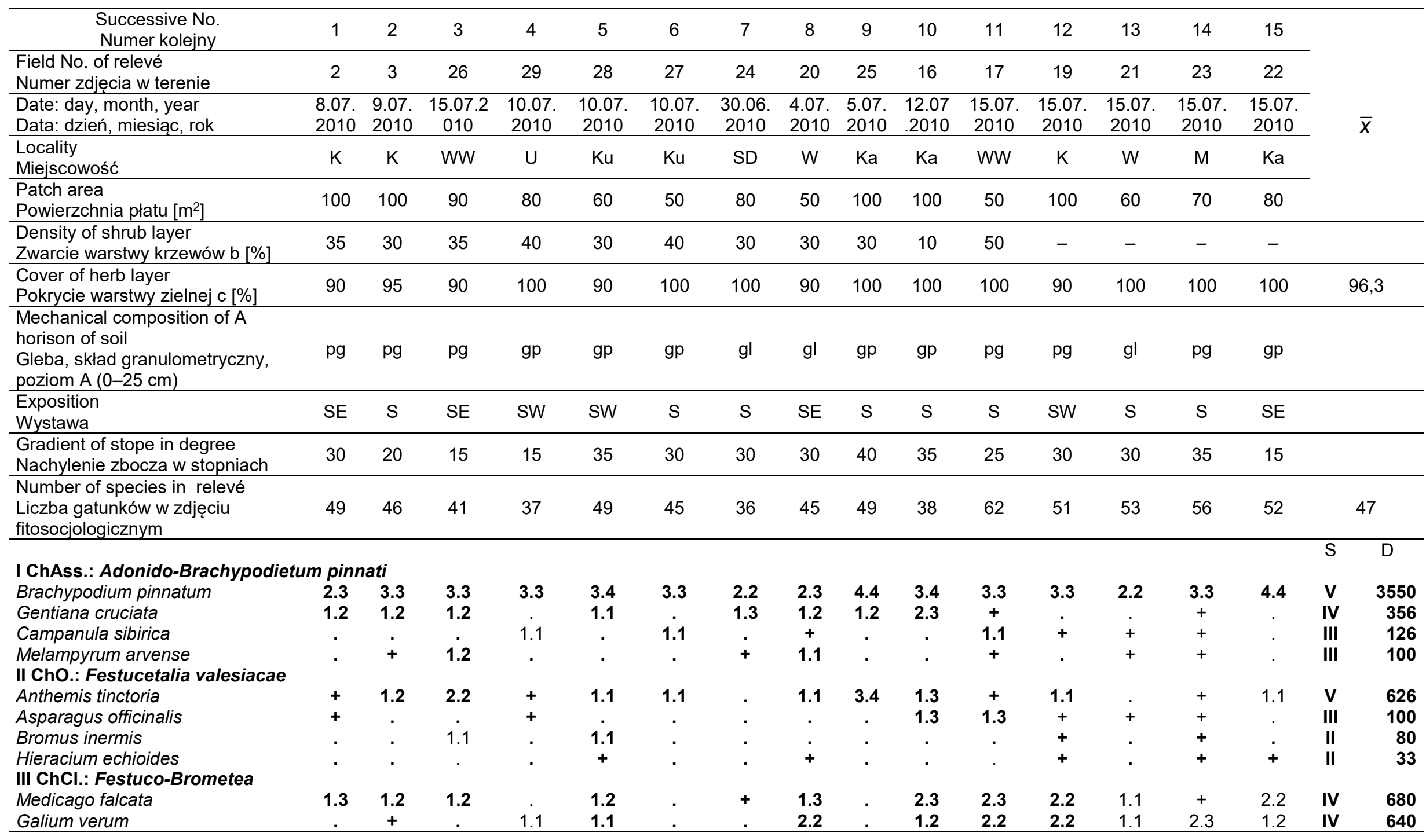


Table. 3. Adonido-Brachypodietum pinnati (Libb. 1933), Krausch 1960 (cont.)

Tabela. 3. Adonido-Brachypodietum pinnati (Libb. 1933), Krausch 1960 (cd.)

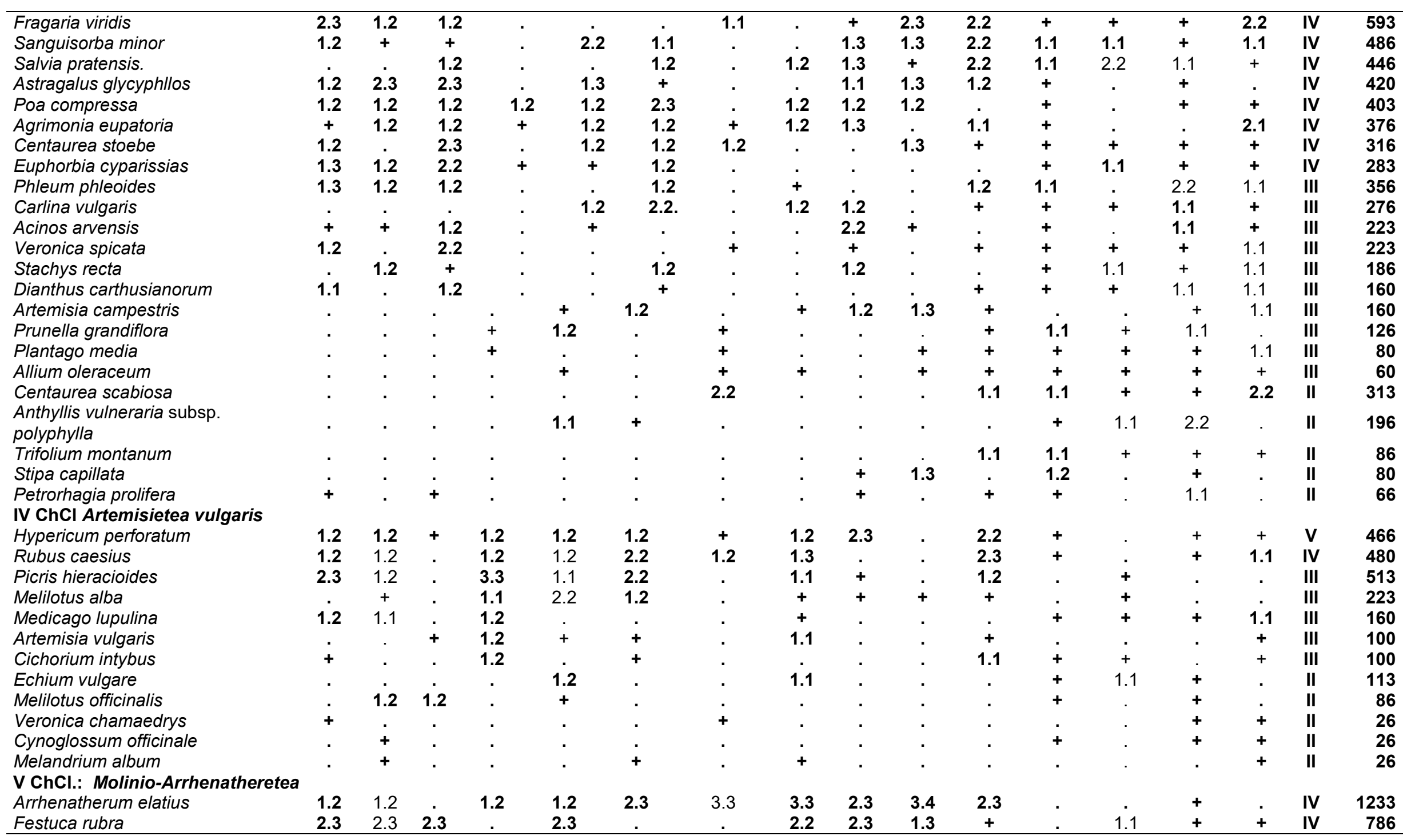


Table. 3. Adonido-Brachypodietum pinnati (Libb. 1933), Krausch 1960 (cont.) Tabela. 3. Adonido-Brachypodietum pinnati (Libb. 1933), Krausch 1960 (cd.)

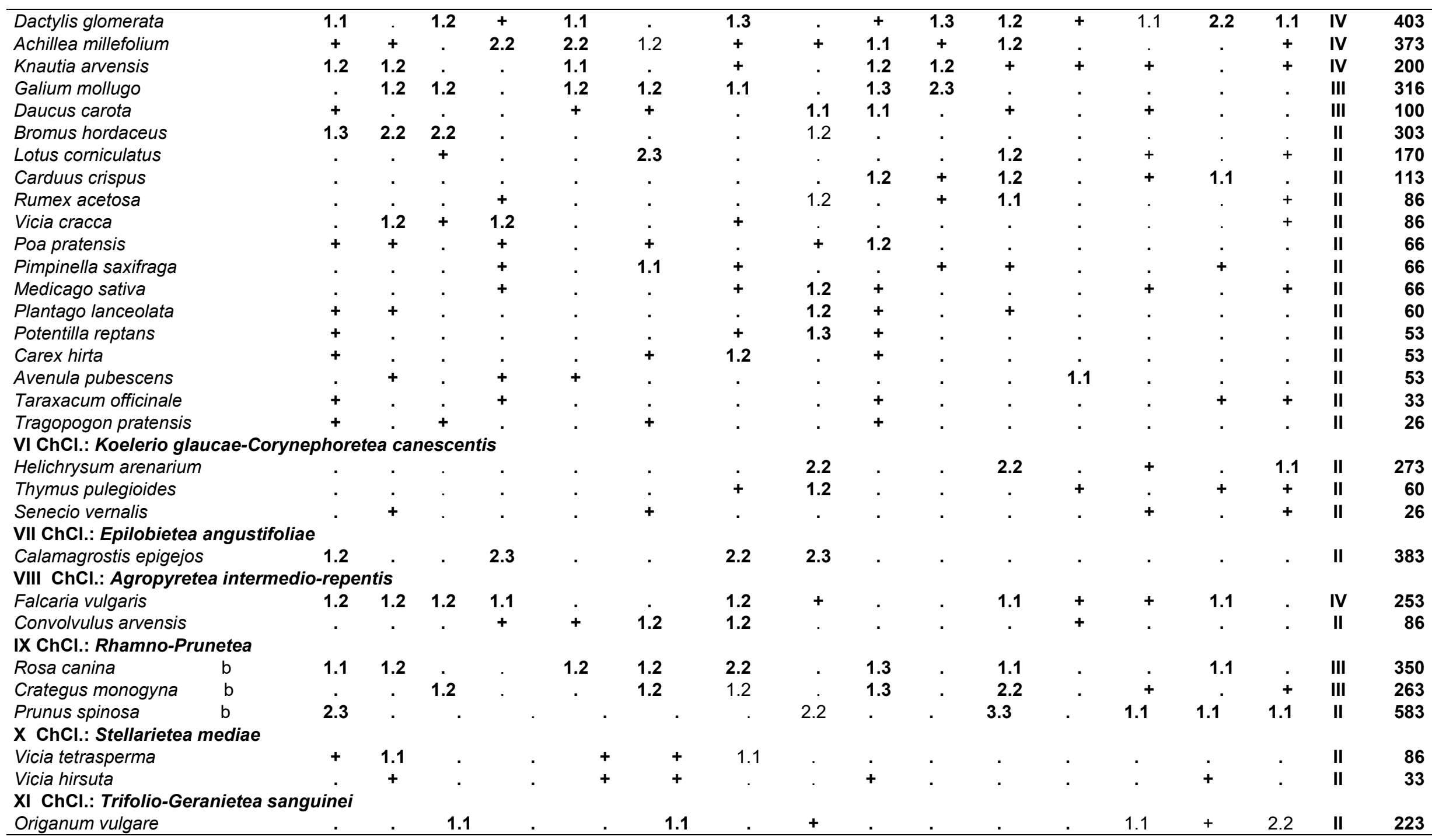


Table. 3. Adonido-Brachypodietum pinnati (Libb. 1933), Krausch 1960 (cont.)

Tabela. 3. Adonido-Brachypodietum pinnati (Libb. 1933), Krausch 1960 (cd.)

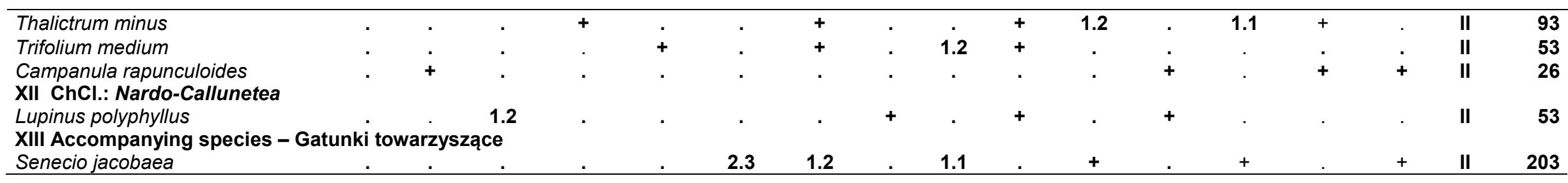

Plant species occurring only in I degree of relevé constance in plant communities. After a name of species the number of the relevé in which species occurred is given and in brackets the quantity degrees and sociability - Gatunki roślin występujące w zbiorowisku wyłącznie w I stopniu stałości (S). Po nazwie gatunku podano numery zdjęć fitosocjologicznych, w których wystąpił gatunek, w nawiasach - stopnie ilościowości i towarzyskości. Explanations: - Objaśnienia: $S$ - phytosociological stability - stałość fitosocjologiczna, D - cover coefficient - współczynnik pokrycia, $\bar{X}$ - medium value - wartości średnie, locality - miejscowości: K - Kamionka, Ka - Kamieniec, M - Moczyły, P - Pargowo, WW - reserve „Wzgórze Widokowe”- rezerwat „Wzgórze Widokowe”.

I: Seseli annuum 11(+); II: Achillea pannonica 12(+); Potentilla arenaria 10(1.3), 11,12(+); III: Ajuga genevensis 3,5(+), 9(1.2); Carex caryophyllea 12,13(+); Koeleria macrantha 11(1.2); Filipendula vulgaris 12(+); IV: Artemisia absinthium 5,11(+); Epilobium montanum 5(+), 10(1.3); Erigeron ramosus 4(+); V: Anchusa officinalis 4,5(+); Bellis perennis 10(+); Briza media 9(1.2); Cerastium holosteoides 4,9(+); Centaurea jacea 9(1.1), 11,12(+); Coronilla varia 13,14(+); Dipsacus silvestris 10(1.2); Galium aparine 8(2.3); Geum urbanum 10(+), 11(1.3); Helianthus tuberosus 4(1.2); Lactuca serriola 10,13(+); Oenothera biennis 10(+); Phleum pratense 9,10(+), 11(1.1); Potentilla argentea 2(+); Prunella vulgaris 9(1.3), 2,13(+); Reseda lutea 9(1.2), 11(+); Rumex crispus 1,9 (+); Tanacetum vulgare 4(1.2); Trifolium pratense 1(+), 9(1.2); T. repens 8,15(+); Urtica dioica 4(1.3); VI: Festuca ovina 8(1.1); Sedum acre 5(1.2); Solidago virgaurea 3(+), 7,8(1.2); Trifolium arvense 11,15(+), 14(1.1); VII: Betula pendula b 1(1.1); VIII: Equisetum arvense 1,8(+); Elymus repens 2(1.2), 3,5(+); Tussilago farfara 5(+), 6(1.2); IX: Euonymus europaea b 11(+); X: Conyza canadensis 1,6,11(+); Geranium pusillum 7(+); Lathyrus tuberosus 2(1.2), 6(2.2), 12(+); XI: Verbascum lychnitis 5(+); Vicia tenuifolia 1,3,5(+); XIII: Arenaria serpyllifolia 6(+); Chenopodium album 2,3(+); Erigeron acris 6(+); Ligustrum vulgare b 13(+); Ononis spinosa 3,14,15(+); Ornithogalum umbellatum 6(+); Quercus robur b 1(1.2), 11(+); Primula veris 11,12(+); Ranunculus bulbosus 5,9(+); Silene vulgaris 3(1.2), 13(+), 15(1.1); Torilis japonica 7(1.2); Trifolium aureum 2(+); Vicia grandiflora 1,2(+). 
The community is floristically rich (141 taxa recorded), on average there were 47 species recorded per relevé. It is characterized by significant density - average coverage is 96.3 (Table 3). Apart from Brachypodium pinnatum, the characteristic species are: Gentiana cruciata (S = IV, D = 356) - Fig. 6, Campanula sibirica $(S=I I I, D=126)$ and Melampyrum arvense $(S=I I I, D=100)$. Common species in the community are also Anthemis tinctoria $(S=V, D=626)$ and Asparagus officinalis $(S=I I I, D=100)$. Stable components of Festuco-Brometea are: Medicago falcata ( $=$ IV, D = 680), Galium verum (S = IV, D = 640), Salvia pratensis $(S=I V, D=446)$, Fragaria viridis $(S=I V, D=598)$, Sanguisorba minor $(S=I V$, $\mathrm{D}=486)$, Astragalus glycyphyllos $(S=I V, D=420)$, Poa compressa ( $=I V, D=409)$, Agrimonia eupatoria $(S=I V, D=376)$, Centaurea stoebe $(S=I V, D=326)$ and Euphorbia cyparissias ( $=$ IV , D = 316) - Table 3. Commonly found are also: Acinos arvensis ( $=$ III, $\mathrm{D}=223)$, Phleum phleoides ( $=\mathrm{III}, \mathrm{D}=356)$, Carlina vulgaris $(\mathrm{S}=\mathrm{III}, \mathrm{D}=276$ ) and Veronica spicata $(S=I I I, D=223)$. In the species composition of the phytocoenosis which lacks pasture and reaping, lush development of meadow vegetation can be observed. From Molinio-Arrhenatheretea the significant components are: Arrhenatherum elatius ( $=$ IV,$D=1233$ ), Festuca rubra (S = IV , D = 786), Dactylis glomerata ( $=\mathrm{IV}, \mathrm{D}=403)$, Achillea millefolium ( $=\mathrm{IV}$, $\mathrm{D}=373$ ), Knautia arvensis ( $=\mathrm{IV}, \mathrm{D}=200$ ). Phytocoenoses of Adonido-Brachypodietum pinnati are inhabited also by ruderal species. They are much less numerous than seminatural species. The most common and numerous of them are Hypericum perforatum $(S=V, D=466)$ and Rubus caesius ( $S=I V, D=480)$. Picris hieracioides $(D=523)$ is also numerous. Shrubs are often found in the association of heath false brome. According to Filipek (1974b), it indicates an intermediate stage in the succession leading to the development of scrubs and then the forest. The succession is confirmed by the participation of Rhamno-Prunetea species in the community and especially: Rosa canina $(S=I I I, D=350)$, Crataegus monogyna ( $=$ III, $D=263)$ and Prunus spinosa $(S=I I, D=583)$. Waldon and Rapacka-Gackowska (2010) confirmed the penetration of the community by scrub species. They report that in the "Płutowskie Slopes" ("Zbocza Płutowskie") reserve in the Vistula River valley there have be significant changes in the floristic composition of grasslands since 1963 when the economic use of the area ceased. $20 \%$ of xerothermic species have disappeared and the total number of grassland patches was reduced sixfold due to the invasion of scrub taxa of Rhamno-Prunetea. The dominant patches of Potentillo-Stipetum capillatae and Adonido-Brachypodietum pinnate now form small enclaves within the slopes that have not yet been covered by shrubs.

Adonido-Brachypodietum pinnati association is quite often recorded in Poland. On Twardowicki Plateau (Silesian Highland) it was distinguished by Babczyńska-Sendek (2005) in the rank of three subassociations A.-B. phleetosum, A.-B. typicum and A.-B. anthericetosum. In the "Brodogóry" reserve, it was also distinguished by Prajs (2010), who used relevés from 2000 and materials by Filipek from 1974. Comparing the relevés with materials by Filipek, she established that there have been no major changes in the floristic composition in this period of time, however part of the patches were characterized by more numerous presence of scrub species of Rhamno-Prunetea, and there has been a strong expansion of meadow communities as well as Rubus caesius and Calamagrostis epigejos. The community of Adonido-Brachypodietum pinnati in the reserve is dominated by a numerous population of Anthericum 
liliago as well as Asperula tinctoria, Stachys recta, Bromus inermis and Achillea pannonica, which are disappearing in Pomerania (Prajs 2003). The association was also described by Heise (2010) within xerothermic grasslands in "Skarpy Ślesińskie" reserve. It is threatened in this area by construction work conducted in the vicinity of the reserve. The community was also distinguished by Waldon (2010) in "Ostnicowe Parowy Gruczna" reserve, and in the Lower Oder Valley it was described by Friedrich and Semczyszyn (2002). The latter recorded 135 species in 40 patches of the community, of which 45 taxa attained only the first grade of phytosociological stability (sporadic species). The number of species per relevé ranged from 21 to 65 , with average at 39 . The phytocoenoses in the area were significantly richer in flora than the community in the area of Owczary. This could have been due to the greater number of the collected relevés. The dominant species are Brachypodium pinnatum ( $S=V, D=4913$ ) and Prunella grandiflora ( $\mathrm{S}=\mathrm{V}, \mathrm{D}=286$ ). Stable components of the community are also species of Festuco-Brometea class: Galium verum $(S=V, D=1343)$, Medicago falcata $(S=V, D=1325)$ and Salvia pratensis $(S=V, D=1281)$. In the dense grasslands of AdonidoBrachypodietum pinnati in the area of Owczary, Czyż et al. (2005) found that the dominant species were: Brachypodium pinnatum ( $=\mathrm{V}, \mathrm{D}=2167)$, Festuca rubra $(S=\mathrm{V}, \mathrm{D}=2000$ ) and Stipa joannis (S = IV, D = 1972). Common (S = IV) were also Stipa capillata, Centaurea stoebe, Achillea pannonica, Thesium linophyllon, Thymus pulegioides, Potentilla arenaria and Ononis spinosa, but they attained slight coverage. The association of Adonido-Brac hypodietum pinnate was also distinguished within the reserves in Owczary by Kutyna et al. $(2011,2012)$. The structure of the community is formed by 78 taxa, with the average of 28 per relevé, which is much less than in the phytocoenoses on the left edge of the Oder River. Plant density is significant $-89.9 \%$. Stable characteristic component of the phytocoenoses is Brachypodium pinnatum ( $=\mathrm{V}, \mathrm{D}=4563)$. Moreover, common and numerous species are: Salvia pratensis $(\mathrm{S}=\mathrm{V}, \mathrm{D}=631)$, Galium verum $(\mathrm{S}=\mathrm{V}, \mathrm{D}=991)$, Prunella grandiflora $(\mathrm{S}=\mathrm{IV}$, $\mathrm{D}=288)$, Stipa joannis $(S=I I I, D=606)$ and Centaurea scabiosa $(S=I V, D=416)$.

\section{CONCLUSIONS}

1. Enclaves of xerothermic grasslands are found within the edge of the Western Oder River from Ustowo to Pargowo. Phytocoenoses are mainly found on southern and south-eastern slopes of the edge and on local elevations.

2. Based on 29 relevés, two associations were distinguished:

a) Potentillo-Stipetum capillatae - internally differentiated into a typical variant and the one with a significant share of shrub communities of Rhamno-Prunetea. The structure of the association, apart from numerous xerothermic grasslands, is formed by sandy grasslands of Koelerio glaucae-Corynephoretea canescentis (particularly common and numerous are: Sedum acre, Festuca ovina and Helichrysum arenarium). The patches of this phytocoenon occur both on soils poorly formed by erosion (SY) formed of loamy sands and on typical eutrophic brown soil (BEt) formed of light loam;

b) Adonido-Brachypodietum pinnati. Phytocoenoses form dense grasslands with the dominance of Brachypodium pinnatum and the majority Molinio-Arrhenatheretea (Arrhenatherum elatius, Festuca rubra, Dactylis glomerata) as well as with a significant participation of scrub communities of Rhamno-Prunetea. 
3. Patches of vegetation developed mainly on typical eutrophic brown soil (BEt) formed of sandy loam and light loam. Typologically varied soils found on the slopes of the edge are characterized by alkaline reaction and a significant content of calcium carbonate. Southern and south-eastern exposition and soil conditions favour the occurrence of xerothermic and sandy grasslands in such biotopes.

4. Frequent and numerous scrub species communities (Rhamno-Prunetea) in some grassland patches of both associations, as well as grasses of Molinio-Arrhenatheretea indicate an intermediate stage in the succession toward the formation of seminatural and shrub communities.

5. In order to preserve the unique flora and the plant communities in the area it should be used extensively (grazing, mowing).

\section{REFERENCES}

Babczyńska-Sendek B. 2005. Problemy fitogeograficzne i syntaksonomiczne kserotermów Wyżyny Śląskiej [Phytogeographic and syntaxonomic issues of xerotherms of the Silesian Uplands]. Pr. Nauk. UŚ Kat. 2296, 1-237. [in Polish]

Barańska K., Jermaczek A. 2009. Poradnik utrzymania i ochrony siedliska przyrodniczego 6210 murawy kserotermiczne. Świebodzin,Wydaw. Lubuskiego Klubu Przyrodników, 3-201. [in Polish]

Bąba W. 1999. Murawy kserotermiczne w planie ochrony Ojcowskiego Parku Narodowego [Xerothermic grasslands in the protection plan of Ojcowski National Park]. Prz. Przyr. 10(1-2), 129-136. [in Polish]

Borowiec S. 1993. Geologia i gleby rejonu Szczecina. Stan środowiska miasta i rejonu Szczecina. Szczecin, Wydaw. Szcz. Tow. Nauk., 67-78. [in Polish]

Celiński F., Filipek M. 1958. Flora i zespoły roślinne leśno-stepowego rezerwatu w Bielinku nad Odrą [The flora and plant communities of forest-steppe reserve in Bielinek on the Oder]. Bad. Fizjogr. Pol. Zach., Ser. B 4, 1-184. [in Polish]

Czyż H., Trzaskoś M., Kitczak T. 2005. Charakterystyka zbiorowisk roślinnych z udziałem Stipa joannis i Stipa capillata na murawach kserotermicznych w Owczarach [The characteristics of plant communities with Stipa joannis and Stipa capillata on xerothermic grasslands in Owczary]. Łąk. Pol. Pozn. 8, 249-253. [in Polish]

Ćwikliński E. 1982. Kserotermiczne murawy koło Nawodnej w województwie szczecińskim [Xerothermic grasslands near Nawodna in Szczecin Province]. Bad. Fizjogr. Pol. Zach., Ser. B 33, 7-27. [in Polish]

Dzwonko Z. 2007. Przewodnik do badań fitosocjologicznych. Vademecum Geobotanicum. Poznań, Wydaw. Sorus SC, 5-304. [in Polish]

Filipek M. 1974a. Kserotermiczne zespoły murawowe nad Odrą i Wisłą na tle zbiorowisk pokrewnych [The xerothermic grassland communities at the rivers Oder and Vistula in comparison to cognate communities]. Bad. Fizjogr. Pol. Zach. Ser. B 27, 45-82. [in Polish]

Filipek M. 1974b. Murawy kserotermiczne regionu dolnej Odry i Warty [The xerothermic grasslands of the lower Oder and Warta region]. Pr. Kom. Biol. Pozn. Tow. Przyj. Nauk. 38, 1-110. [in Polish]

Friedrich S. 2000. Flora i roślinność rezerwatu częściowego „Wzgórze Widokowe nad Międzyodrzem” koło Szczecina [Flora and vegetation of „Wzgórze Widokowe nad Międzyodrzem” partial reserve near Szczecin]. Folia Univ. Agric. Stetin. 213(85), 59-80. [in Polish]

Friedrich S., Semczyszyn L. 2002. Murawy kserotermiczne krawędzi doliny Dolnej Odry, w: Dolina Dolnej Odry. Monografia przyrodnicza Parku Krajobrazowego. Red. J. Jasnowska. Szczecin, Wydaw. STN ZAPOL, 163-186. [in Polish]

Heise W. 2010. Murawy kserotermiczne doliny Kanału Bydgoskiego - rozmieszczenie wybranych gatunków rzadkich, zarys historii użytkowania i perspektywy zachowania, w: Ciepłolubne murawy w Polsce - stan zachowania i perspektywy ochrony. Red. H. Ratyńska, B. Waldon. Bydgoszcz, Wydaw. Uniw. Kazimierza Wielkiego, 171-183. [in Polish] 
Jasnowska J. 1973. „Wąwóz Kamieniec” - projektowany rezerwat florystyczny w powiecie szczecińskim [,Kamieniec Gorge" - a projected botanical reserve in the district of Szczecin]. Chrońmy Przyr. Ojcz. 4, 31-37. [in Polish]

Jermaczek A., Pawlaczyk P., Rybaczyk E. 2005. Murawy kserotermiczne nad Odrą. Świebodzin, Wydaw. Lubuskiego Klubu Przyrodników, 5-16. [in Polish]

Koćmit A., Niedźwiecki E., Zabłocki Z. 1981. Gleboznawstwo z elementami geologii. Szczecin, Wydaw. Nauk. AR, 1-238. [in Polish]

Kostuch R., Misztal A. 2006. Zasiedlanie wyeksploatowanych kamieniołomów przez roślinność. [Repopulation of depleted quarries by vegetation]. Zesz. Nauk. Akad. Rol. im. H. Kołłątaja Krak., Inż. Środ. 433(27), 287-296. [in Polish]

Koźmiński Cz. 1983. Agroklimat województwa szczecińskiego [Agroklimat voivodship of Szczecin]. Pr. Nauk. STN Wydz. Nauk. Przyr. Rol. 50, 3-194. [in Polish]

Kutyna I., Drewniak E., Młynkowiak E. 2011. Xerothermic grasslands within the area of the extern margin of the Oder River valley in the vicinity of town of Górzyca. Ann. UMCS, Sec. C 66(1), 55-84.

Kutyna I., Drewniak E., Młynkowiak E. 2012. Zbiorowiska muraw kserotermicznych i piaskowych na krawędzi doliny Odry w Owczarach [Plant communities within xerothermic and psammophilous grasslands on the edge of the Oder river valley in Owczary]. Folia Univ. Agric. Stetin., Agricultura 293(21), 61-87. [in Polish]

Kutyna I., Malinowska K. 2012. Inuletum ensifoliae Kozł. 1925 w obrębie opuszczonego kamieniołomu „Piotrawin” położonego na krawędzi Wisły [Inuletum ensifoliae Kozł. 1925 in the area of the quarry "Piotrawin" situated at the edge of the Vistula river]. Folia Pomer. Univ. Technol. Stetin., Agric., Aliment., Pisc., Zootech. 296(23), 53-80. [in Polish]

Kutyna I., Malinowska K. 2015a. Plant communities on the flat ridge of the "Piotrawin" quarry located in the vicinity of Vistula near Józefów on the Vistula bank in Opole Lubelskie county. Folia Pomer. Univ. Technol. Stetin. Ser. Agric., Aliment., Pisc., Zootech. 316(33)1, 57-80.

Kutyna I., Malinowska K. 2015b. Plant communities on the ridge of the "Piotrawin" quarry 19 years after technical and biological reclamation. Folia Pomer. Univ. Technol. Stetin., Agric., Aliment., Pisc., Zootech. 320(35)3, 41-58.

Kutyna I., Malinowska K., Malinowski R. 2016. Soil conditions and plant communities on the summit, the slope and the depression on the edge of west Oder. Folia Pomer. Univ. Technol. Stetin., Agric., Aliment., Pisc., Zootech. 328(39)3, 123-158.

Marcinek J., Komisarek J. 2011. Systematyka gleb Polski [Soil systematics Polish]. Rocz. Glebozn. 62(3), 1-193. [in Polish]

Matuszkiewicz W. 2007. Przewodnik do oznaczania zbiorowisk roślinnych Polski. Warszawa, PWN, 5-537. [in Polish]

Mirek Z., Piękoś-Mirkowa H., Zając A., Zając M. 2002. Flowering plants and pteridophytes of Poland a checklist. Kraków, W. Szafer Institute of Botany, Polish Academy of Science, 5-442.

Perzanowska J., Kujawa-Pawlaczyk J. 2004. Murawy kserotermiczne Festuco-Brometea, w: Poradnik ochrony siedlisk i gatunków Natura 2000 - podręcznik metodyczny. Tom 3. Red. J. Herbich. Warszawa, Ministerstwo Środowiska, 117-139. [in Polish]

Prajs B. 2003. Pomorskie enklawy muraw stepowych - współczesność i przyszłość, w: Człowiek i środowisko przyrodnicze Pomorza Zachodniego. Red. S. Rogalska, J. Domagała. Szczecin, Oficyna IN PLUS, 35-38. [in Polish]

Prajs B. 2010. Rezerwaty kserotermiczne w dolinie Płoni - problemy ochrony siedlisk kserotermicznych na terenach rolniczych, w: Ciepłolubne murawy w Polsce - stan zachowania i pespektywy ochrony. Red. H. Ratyńska, B. Waldon. Bydgoszcz, Wydaw. Uniw. Kazimierza Wielkiego, 260-273. [in Polish]

Radomski J., Jasnowska J. 1964. Roślinność otwartych zbiorowisk na zachodniej krawędzi doliny dolnej Odry. Cz. I, II. Badania florystyczne na zachodniej krawędzi doliny dolnej Odry [Vegetation of open communities on the western edge of the Lower Oder Valley. Part I, II. Floristic studies on the western edge of the Lower Oder Valley]. Zesz. Nauk. WSR Szczec. 17, 85-106. [in Polish] 
Radomski J., Jasnowska J. 1965. Roślinność zbiorowisk murawowych na zachodniej krawędzi doliny dolnej Odry. Cz. III. Charakterystyka fitosocjologiczna muraw kserotermicznych na zachodniej krawędzi doliny dolnej Odry [Vegetation of grasslands communities on western edge of the Lower Oder Valley. Part III. Phytosociological characteristics of xerothermic grasslands on the western edge of the Lower Oder Valley]. Zesz. Nauk. WSR Szczec. 19, 69-83. [in Polish]

Waldon B. 2010. Walory przyrodnicze szaty roślinnej rezerwatu stepowego „Ostnicowe Parowy Gruczna”, w: Ciepłolubne murawy w Polsce - stan zachowania i perspektywy ochrony. Red. H. Ratyńska, B. Waldon. Bydgoszcz, Wydaw. Uniw. Kazimierza Wielkiego, 139-149. [in Polish]

Waldon B., Rapacka-Gackowska A. 2010. Stan zachowania i problemy muraw kserotermicznych w dolinach Wisły i Noteci, w: Ciepłolubne murawy w Polsce - stan zachowania i perspektywy ochrony. Red. H. Ratyńska, B. Waldon. Bydgoszcz, Wydaw. Uniw. Kazimierza Wielkiego, 110-127. [in Polish]

Wysocki C., Sikorski P. 2002. Fitosocjologia stosowana. Warszawa, Wydaw. SGGW, 1-449. [in Polish]

\begin{abstract}
Based on 29 relevés were made in the area of the edge of Western Oder (Ustowo-Pargowo) two xerothermic grass associations were distinguished. Potentillo-Stipetum capillatae phytocoenon is internally differentiated into the typical variant and the one with a significant share of shrub communities with Rhamno-Prunetea. Apart from numerous species of xerothermic grasses, the structure of the association is formed by sandy grasses taxa with Koelerio glaucae-Corynephoretea canescentis (Sedum acre, Festuca ovina and Helichrysum arenarium are particularly frequent). Patches of this phytocoenon are found both on soils poorly formed by erosion (SY) made of clayey sands and on typical eutrophic brown soils (BEt) formed of light loam. Adonido-Brachypodietum pinnati phytocoenoses form dense grasslands with the dominance of Brachypodium pinnatum and the grasses of Molinio-Arrhenatheretea (Arrhenatherum elatius, Festuca rubra, Dactylis glomerata) together with the significant share of shrub communities species with Rhamno-Prunetea. Patches of vegetation have developed mainly on typical eutrophic brown soils (BEt) formed of sandy loam and light loam. Typologically varied soils found on the slopes of the edge are characterized by alkaline reaction and a significant content of calcium carbonate. Southern and south-eastern exposition of the slopes and soil conditions are favourable for the occurrence of xerothermic and sandy grasslands. Frequent and numerous presence of shrub communities species (Rhamno-Prunetea) in some patches of both associations, as well as grasses of Molinio-Arrhenatheretea, indicate an intermediate stage in the succession toward the development of seminatural communities as well as shrub communities. In order to preserve the unique flora and the plant communities in the area it should be used extensively (grazing, mowing).
\end{abstract}

The authors thanks PhD Marek Podlasiński (West Pomeranian University of Technology, Szczecin) for the execution of Fig. 3 and 4. 